\title{
The Anti-Japanese Land Laws of California and Ten Other States*
}

\author{
Dudley O. McGovney
}

THE LAW in nine states of the United States puts every alien in the world either completely or substantially on an equality with a citizen with respect to acquiring and holding real property within their borders, except aliens who are racially ineligible to naturalization under the laws of the United States. In these states both resident and nonresident aliens racially ineligible to naturalization, but no others, are denied the privilege of aquiring any legal interest in land for agricultural purposes. In some of these states, probably in all, they are also denied the privilege of owning, as distinguished from holding under lease, any land for any purpose whatsoever, even for residential purposes.

California began this discrimination between "ineligible aliens"1 and all others in $1913 .^{2}$ The statute of that year was stiffened in $1920^{\circ}$ and subsequent additions have made it even more drastic. ${ }^{4}$ Eight states have followed her lead with variations on relatively minor points: Arizona in $1917 ;^{5}$ Louisiana, $1921 ;^{6}$ New Mexico,

*All rights to reprint any or all of this article are reserved by the author.

†A.B., 1901, Indiana University;'M.A., 1904, Harvard University; LL.B., 1907, Columbia University. Professor of Law, University of California.

In the remainder of this essay the expression "inehigible aliens" will be used to mean aliens who are ineligible to naturalization solely because of their race. While any alien is ineligible to naturalization, whatever his race, if he lacks any one of several other qualifications required for naturalization, the laws herein discussed have been interpreted as applying solely to those "ineligible aliens" whose ineligibility is due to their race.

2 Cal. Stats. 1913, p. 206.

3 Initiative Act of 1920, Cal. Stats. 1921, lxxxiii.

4 Cal. Stats. 1923, p. 1020; ibid. 1927, p. 880; ibid. 1943, pp. 2917, 2999; ibid. 1945. p. 2164 (enjoining the Attorney General and district attorneys to enforce the law, and sharpening "escheat" proceedings); ibid. p. 217 7 (declaring the statute of limitations inapplicable to "escheat" proceedings); ibid. p. 2552 (similar to the preceding); $i b i d$. p. 2739 (appropriating $\$ 200,000$ for investigation and prosecution of violation of the law). For the present law in full, see CaI. GeN. Laws, Acts 260, 261.

5 Ariz. Laws, 1917, p. 56; ibid. p. 25; ARIz. CODE (1939) \$§ 71.201-71.205.

${ }^{6}$ LA. Const. (1921) art. XIX, § 21. 
1922 ${ }^{7}$ Idaho, $1923 ;^{8}$ Montana, $1923 ;^{9}$ Oregon, $1923 ;^{10}$ Kansas, $1925^{11}$ and Utah, 1943.12

Wyoming recently became the tenth state to enact laws aimed at racially ineligible aliens. By Act of February 10, 1943, ${ }^{13}$ such aliens, except Chinese nationals, ${ }^{14}$ were barred from acquiring any interest in real property "or having in whole or in part the beneficial use thereof." It seems, however, that insofar as this statute affects aliens residing in Wyoming, it is in violation of the state constitution, article I, section 29, which reads: "No distinction shall ever be made by law between resident aliens and citizens as to possession, taxation, enjoyment and descent of property." Thus the statute, if not held void as a whole, operates only against nonresidents. Since it seems that the rules of the common law are in force in Wyoming with respect to other nonresident aliens ${ }^{15}$ an odd discrimination results between two classes of nonresident aliens. Nonresident aliens, of races to which the privilege of naturalization is not extended are treated more severely by the statute than are other nonresident aliens by the common law.

The Arkansas legislature in 1943 enacted an anti-Japanese land law. It declares that "no Japanese or a descendant of a Japanese shall ever purchase or hold title to any lands in the State of Arkansas." Nowhere does it use the word "alien" and on its face it applies to American citizens of Japanese ancestry as well as to alien Japanese. As applied to American citizens the statute manifestly violates the Fourteenth Amendment. As applied to resident Japanese aliens it violates the state constitution: "No distinction shall ever be made by law between resident aliens and citizens in regard to possession, enjoyment or descent of property."17

The statute is unique in that it expressly applies exclusively to Japanese. It makes no use of the concept "ineligible to naturaliza-

$\tau$ By amending N. M. CoNsT. (1911) art. II, $\S 22$.

8 Idaho Laws 1923, p. 160; IDAFO CODE (1932) \$\$ 23.101-23.1I2.

9 Mont. Laws 1923, p. 123; Mont. REv. CoDE (1935) $\$ \$ 6802.1-6802.8$.

10 Ore. Laws 1923, p. 145; ORE. CoMr. LAws (1940) $\$ \$ 61.101-61.111$.

11 Kan. Laws 1925, p. 277; Kan. Gen. Stat. (Corrick, 1935) \$\$ 67.701-67.711.

12 Utah Laws 1943, p. 127.

13 Wyo. Laws 1943, p. 33.

14 It was not until the Act of December 17, 1943, 57 STaTs. (1943) 600, that Congress removed the racial bar to naturalization of Chinese aliens. *

15 See Bamforth v. Thmsen (1922) 28 Wyo. 282, 308, 204 Pac. 345, 354.

16 Ark. Acts 1943, p. 75.

17 ARk. Const. (1874) art. II, \& 20. 
tion" and consequently, if valid, it would apply to Japanese aliens even though Congress should make them eligible to naturalization. Accordingly, Arkansas is not counted as among the states that have "ineligible alien" land laws. Since those laws are in reality aimed at the Japanese, Arkansas raises to eleven the count of states that have anti-Japanese land laws. In 1925 the Arkansas legislature did enact an "meligible alien" land law closely imitating the California law. The supreme court of the state held the statute void, apparently wholly void, as being in conflict with the provision of the constitution above quoted..$^{18}$ The Act of 1943 may also be held to be void as a whole. In any event it has no validity beyond its application to nonresident Japanese aliens.

The legislators of Wyoming and Arkansas will be greatly disappointed to discover that their statutes will not operate against resident Japanese aliens. While all of the "ineligible alien" land laws, except Wyoming's, operate against nonresident aliens, nonresidents were never mentioned in the propaganda advocating adoption of the laws. The avowed purpose of these laws has always been to discourage residence of "ineligible aliens" in the state. It seems that nonresident aliens were inadvertently embraced in the general term "ineligible aliens" used to define a class of residents who were to be discriminated against. From the standpoint of the constitutionality of these discriminatory laws, it is their operation in depriving a special class of residents of economic opportunities accorded to all other residents, whether aliens or citizens, that is important. The Fourteenth Amendment's command is that no state shall deny to any person within its jurisdiction the equal protection of the laws.

Before stating with more precision the scope of rights denied to "ineligible aliens" by these laws, let us look at their racial operation. Aliens of the brown or Malay race, except Filipinos ${ }^{19}$ of the

18 Applegate v. Lum Jung Luke (1927) 173 Ark. 93, 291 S. W. 978.

10 The "ineligible alien" laws lrave never applied to Filipinos. Upon the cession of the Philippines to the United States all Spanish nationals residing there, except such of those born in European Spain as elected to retain Spanish nationality, became nationals of the Umited States. Thus they were not aliens, and the California law expressly applied to aliens only. Consequently it has been held that the California law did not apply to them. Alfafara v. Fross (1945) 26 Cal. (2d) 358,159 P. (2d) 14. The obiter dictum of Justice Cardozo to the contrary was, therefore, an error. See Morrison v. California (1934) 291 U.S. 82, 95.

The privilege of naturalization, clranging from the status of noncitizen national to the status of citzen, was granted to the white and negro natives of the Philippines, provided they came to reside in a state or "organized territory", by Act of June 29, 1906, 
same race, and aliens of the yellow or Mongolian race, except Chinese of the same race, are denied rights which aliens of the white or Caucasian race, aliens of the black or Negro race, and aliens of the red or American Indian race are permitted to enjoy without limitation. Thus eligibility of aliens to possess these particular rights follows a very queer pattern, or rather, is patternless, like a crazy quilt. Note that brown and yellow patches may appear in the quilt if they are Filipino aliens or Chinese aliens.

There may also be some patches whose race or color is dubious. These are aliens of races indigenous to British India, called Hindus in the popular parlance of Americans. When naturalization was confined to white and Negro aliens, the Supreme Court held that Hindus are neither, ${ }^{20}$ but surely they are not of the red, yellow, or brown races. Whatever their race, dark Hindu patches are included in the crazy quilt.

The patternless craziness does not end there. Even an alien whose blood is seven-sixteenths Japanese or Korean may acquire land in California if the other nine-sixteenths is wholly of the red, black, or white race, or Hindu, or Chinese, or Filipimo, or a combination of any or all of these. So may any alien who is seven-sixteenths Malay if the rest of his blood is wholly of a qualifying kind or a combination of qualifying kinds. The fraction of seven-sixteenths is taken as an example. The actual rule is that if eligible blood preponderates, however slightly, the alien is eligible to acquire real property in California. Here we have the possibility of patches of intermediate color. On the other hand if Mongolian blood other than Chinese preponderates in the veins and arteries of an alien, or Malay blood other than Filipino predominates, that alien may not get into the quilt.

Yet I am talking law, and not mdulging in a purely imaginative surrealistic painting.

To illustrate even more specifically the conception these states have of their yellow peril: if an alien is nine-sixteenths of Chinese blood and seven-sixteenths Japanese he may get into the quilt, but if

\$30, 34 STAT. 606. Later the privilege was extended to those Filipinos regardless of race who enlisted in and served in the United States Navy, Marine Corps, or the Naval Auxiliary Services. Act of May 9, 1918, 40 Stat. 542, 547.

Now that the Philippines have become an independent foreign country, all Filipinos are aliens, except the few who became citizens of the United States under the statutes cited in the previous paragraph. But even so the "ineligible alien" laws do not now apply to them for with respect to all Philippine nationals the racial bar to their naturalization lias now been abolished. Act of July 2, 1946; see infra note 21.

20 United States v. Thind (1923) 261 U.S. 204. 
the proportions are the reverse the line between safety and peril to the welfare of these states is regarded as having been crossed. This is not sarcastic humor. It is legal talk. It bears on the rationality of the discrimination made by these laws and therefore upon their constitutionality.

All of these diversities result from the fact that the laws of these states define the proscribed class as aliens who are ineligible to naturalization under the laws of the United States, and thereby adopt the vagaries of the naturalization law, set out in the footnote. ${ }^{21}$

HOW MANY "INELIGIBLE AIIENS" RESTE IN THE UNITED STATES

AND THE TEN STATES?

Prior to 1940, Census reports did not clearly divide our nonwhite population by citizenship and alienage. Formerly I estimated from figures in the Census of 1920 that there were 134,135 aliens residing in the contmental United States that were racially ineligible to naturalization, ${ }^{22}$ but that figure included 43,107 alien Chinese, 6,299 alien American Indians (foreign born) and some Hindus, classes which now are racially eligible to naturalization.

The number of aliens racially ineligible to naturalization under the present law who resided in the continental United States in 1940, and the number of American born citizens of the same races, ${ }^{23}$ were:

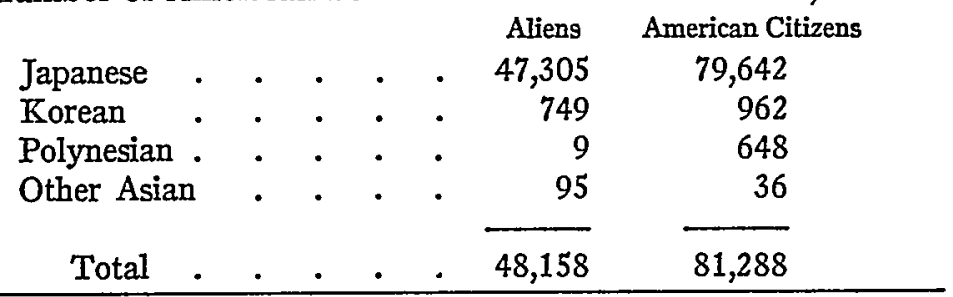

21 "The right to become a naturalized citizen ... shall extend only to-

(1) white persons, persons of African nativity or descent, and persons who are descendants of races indigenous to the continents of North or South America or adjacent islands and Filipino persons or persons of Filipino descent;

(2) persons who possess, either singly or in combination, a preponderance of blood of one or more of the classes specified in clause (1);

(3) Chinese persons and persons of Chinese descent, and persons of races indigenous to India; and

(4) persons who possess, either singly or in combimation, a preponderance of blood of one or more of the classes specified in clause (3) or, either singly or in combination, as much as one-half blood of those classes and some additional blood of one of the classes specified in clause (1)." 8 U.S.C. (1940) \& 703, as last amended by PUB. L. No. 483, 79th Cong. 2d Sess. (July 2, 1946).

${ }^{22}$ McGovney, Race Discrimination in Naturalization (1923) 8 IowA L. BuLL. 211, 215.

23 16th Census of the United States: 1940, Characteristics of the Nonwhite Population, p. 2. 
With the 47,305 Japanese aliens may be compared the 37,242 Chinese aliens and approximately 45,000 Filipinos in the United States in 1940, the two latter groups being not now racially ineligible to naturalization.

Since in 1940 there were 4,741,971 aliens residing in the continental United States, ${ }^{24}$ the "ineligible aliens" were a trifle over one per cent of all our alien residents. Since entry into the United States by "ineligible aliens" for the purpose of permanent residence has been entirely cut off by our immigration law since $1924,{ }^{25}$ it is evident that death, deportation, and voluntary withdrawal have materially reduced the 1940 total of 48,158 . I mention this number in the whole of the continental United States because it is the maximum number that can legally migrate into the ten states that have "ineligible alien" land laws, not that it is likely that all should do so.

It is more pertinent to inquire how many "ineligible aliens" reside in the ten states. How many of their residents are these states harassing? Let us look at California, the progenitor of this type of law, the one state that is now making extraordinary exertions to enforce it. California has a greater number of "ineligible alien" residents than any other state; although the nuniber is small in comparison to her total population or to the total number of aliens residing in the state.

The Census of 1940 does not show how many Korean, Polynesian, Malay, or "other Asian" aliens resided in Califormia. Inasmuch as there were only 853 of them, all told, in the continental United States, the number of them in California is too small to impeach the statement that her alien land law has no significance except as it operates against Japanese. Thus the law now operates solely against the race hostility toward which motivated its enactment. It is true that in the period of its origination, 1913-1920, there were other classes of aliens residing in California who, by the naturalization law as it then stood, were ineligible to naturalization. Of these the largest number were Chinese. By that time, however, the earlier hostility toward Chinese had almost wholly disappeared. In all the flood of hostile legislation against the Chinese in California which began in 1855 and ended in 1891 (see Appendix A) the legislature made no attempt to curtail the rights of Chinese aliens to hold realty, and in that respect they had equal rights with citizens. Although the

24 ReP. AtT'Y GeN. 1941, at 259.

2543 Stat. (1924) $153,102,8$ U. S. C. (1940) § 213 (c). 
propaganda in support of the anti-alien land law was aimed at "Oriental occupancy" of farm lands, it was conceded that Chinese holdings were slight. ${ }^{2 B}$ The agitators never mentioned the six thousand foreign born and "ineligible alien" American Indians in California. While there was some reference to Hindus, the weight of decision in the lower federal courts ${ }^{27}$ at that time was that Hindus were not racially ineligible to naturalization..$^{28}$ Furthermore the occupancy of farn lands by Hindus was insignificant. ${ }^{29}$

The Chinese aliens, the American Indian aliens, and the few resident Malay and Polynesian aliens were as a matter of indifference embraced within the law's generic term, "meligible aliens". The law would have been inanifestly unconstitutional if it had expressly applied exclusively to Japanese.

It is an indubitable historical fact that the "ineligible alien" land law would not have been enacted had it not been for the Japanese already in California, and the expectation of further immigration. In its imitial decision in 1922 under this law, the supreme court of California alluded to "The object sought to be attained by these statutory provisions, that is, to discourage the coming of Japanese into this state . . ." "To discourage the coming" was an understatenient, for the object was also to discourage the stay of those

26 The statistics compiled by the State Board of Control in 1920 with regard to California city lots and farm lands occupied by Orientals, both American citizens and aliens, showed:

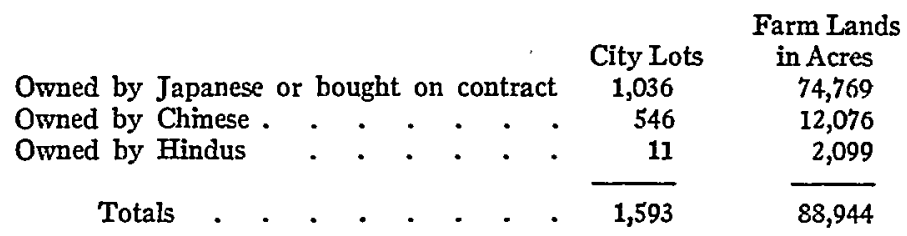

Under lease or crop contract:

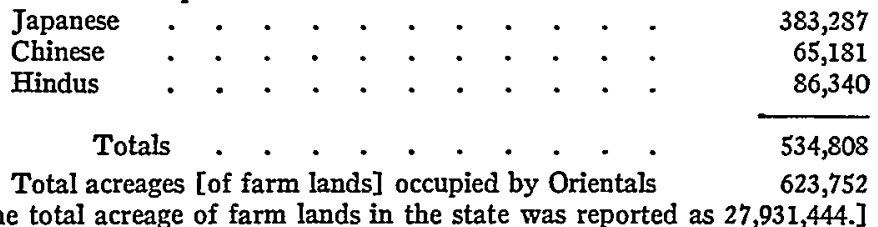

[The total acreage of farm lands in the state was reported as $27,931,444$.]

Rep. Cal. State Bd. Control, California and the Oriental (1920) at 47.

27 McGovney, op. cit. supra note 22, at 145, n. 41.

23 The decision of the Supreme Court holding Hindus racially ineligible to naturalization came in 1923. United States v. Thind, supra note 20.

20 See supra note 26.

30 Estate of Yano (1922) 188 Cal. 645, 658, 206 Pac. 995, 1001. 
who had already come. The court readily took judicial notice of the current agitation and propaganda against the Japanese. ${ }^{31}$

The "Argument in Favor of Proposed Alien Land Law" in the pamphlet officially mailed to every voter before the election at which the Initiative Act of 1920 was to be voted on, said: "Its primary purpose is to prohibit Orientals who cannot become American citizens from controlling our rich agricultural lands .... Orientals, and more particularly Japanese, [have] commenced to secure control of agricultural lands in California ...." Further on is a reference to "Orientals, largely Japanese". These are the only references to Orientals in general, while repeatedly the argument is directed against the Japanese alone, without reference to other Orientals. Why should California "give to Japanese" rights which Japan denies to Americans in Japan, asks the Argument. There are statements about "long leases of these lands by Japanese"; "land is occupied by Japanese"; "control of the products of the soil by a unified interest such as the Japanese"; and "Japanese legitimately here may remain indefinitely ...."

This extrinsic evidence of the meaning of the law as understood by its enactors, in this case the state's electorate, is more persuasive than even committee reports on bills in legislatures, of which the courts take judicial notice to ascertain the intention of lawmakers.

The Census of 1940 reports that there were 33,569 Japanese aliens residing in Califorma. This compares with 16,676 alien Chinese residents to whom the law no longer applies, and with 31,408 Filipinos to whom the law never applied, ${ }^{32}$ to mention two groups which at times have also been objects of race prejudice in California.

The number of Japanese aliens in California is now materially less than in 1940. Death, deportation, voluntary return to Japan, and departures to other parts of the United States have greatly reduced the number. A careful estimate by highly informed students of the subject is that there are now only 25,000 alien Japanese in California. $^{33}$

31 See McWmilams, Prejudice (1944) 14 et seq.

32 See supra note 19.

33 The following memorandum was made at my request by Professor Dorothy S. Thomas, Rural Sociologist on the Giannini Foundation of the Universitv of California, and Richard S. Nishimoto, Research Assistant, authors of The Spoilage, Japanese American Evacuation and Resettlement, University of California Press, 1946:

"All of the approximately 33,000 Japanese aliens resident in California at the outbreak of the war were ordered to evacuate the State. About 4,000 were interned by the Department of Justice (our estimate), about 700 were permitted to remain in the cus- 
It is a notable fact that California has more aliens of all nationalities than any other state in the Union except New York. ${ }^{34}$ In 1940 California's aliens numbered $526,937 . .^{35}$ Assuming that only half a million of then are still aliens and reside in California today, only one in twenty is Japanese. It is this small fraction of her alien residents against which she discriminates.

It is pretended that California's welfare would be jeopardized if the 25,000 Japanese alien residents could legally acquire interests in agricultural land. The number of potential farm-owning family units is substantially less than the total figure because of marriages and other family relations in the group. Besides, the Census of 1940 shows that fifty-eight per cent of the alien Japanese in California resided in urban centers of 2,500 population and upward. ${ }^{36}$ Furthermore, the occupational statistics showed large numbers of alien Japanese engaged in nonfarming occupations. ${ }^{37}$ While it is true that the denial

tody of hospitals and institutions (our estimate), 1,315 voluntarily left the State (U.S. Army. Western Defense Command and Fourth Army. Final Report. Japanese Evacuation from the West Coast, 1942. Washington, Government Printing Office, 1943, p. 112.) The bulk of them were confined in relocation projects administered by the War Relocation Authority.

"How many of these 33,000 have since returned to California? The question cannot be answered directly and simply. The cohort of 33,000 had, according to our estimates, been reduced by death to 31,000 ; and by voluntary deportation to Japan to, probably, 29,000 .

"When WRA camps closed during 1946, 20,788 Japanese aliens moved directly from camps to Cahifornia communities, and 24 had earher returned by individual Anny permit. (U.S. Department of Interior, War Relocation Authority. The Evacuated People, p. 42.) There are numhers of Japanese ahens, formerly residents of California, who have resettled in other parts of the country and may or may not return to this area. There are, similarly, ahens, formerly residents of Washington and Oregon, some of whom are probably included in the 20,788 , who came in the 1946 movement to California (since the statistics do not show whether or not the 20,788 were formerly residents of the State). If, on the most improbable assumption that every Japanese alien who left relocation projects for any destination whatsoever had decided, during the past year, to come to California, the total number could not exceed 38,000. (The Evacuated People, p. 42, shows the total number of aliens resettling anywhere in the U.S. from WRA cainps as 38,351.) Our own considered judgment, which cannot yet be verified by statistics, is that there are not more than 25,000 alien Japanese now resident in the State."

34 In 1940, 25.7 Der cent of all aliens in the continental United States resided in New York, while 11.1 per cent resided in California. Pennsylvania had the next largest share, 7.6 per cent, and thirteen states had each only one-tenth of one per cent.

35 Rep. Atr'y GeN. 1941, at 259.

36 16th Census of the United States: 1940, Characteristics of the Nonwhite Population, Table 33.

37 The following table shows the occupations of the 23,208 ahen Japanese, fourteen years of age and older, employed in California in 1940. For comparison it also shows 
of land ownership has artificially affected their preferences, it is apparent that if the restriction were removed far less than 20,000 alien Japanese family units would become land owners. ${ }^{38}$ There are further reasons why the number of alien Japanese farm owners would be small. The alien Japanese in the United States are aged people, ${ }^{80}$ all having immigrated before 1924 . In fact it is said by conipetent authority that almost half of them arrived before $1910 .{ }^{40}$ In 1940 all but 2,760 of the alien Japanese in California were thirty-five years of age or older, which means that the minimum age of all but a few is now forty-two years. But many of them are older. In 1940, 20,869 were forty-five years of age or older; the minimum age of the survivors is now fifty-two. Seventeen per cent of them had passed their sixtieth birthday by $1942 .{ }^{41}$ Many of these aged and aging Japanese

the occupation of the next largest nonwhite alien group, 22,961 Filipinos, fourteen years of age and over, a group to which the anti-alien land law does not apply.

\section{CHARACTERISTICS OF NONWHITE POPULATION, 1940}

\begin{tabular}{|c|c|c|c|c|c|c|c|c|}
\hline & & & & & & & Japanese & Filipinos \\
\hline Professional workers & . & . & 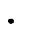 & $\cdot$ & $\theta^{\circ}$ & $\cdot$ & 589 & 109 \\
\hline Semi-professional workers & . $\cdot$ & . & $\cdot$ & • & . & . & 102 & 38 \\
\hline Farmers and farm managers & . & . & & . & & 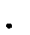 & 4,134 & 348 \\
\hline Proprietors, managers, and & officials & othe & & han & farn & & 3,169 & 251 \\
\hline Clerical, sales and kindred & worker: & & & & . & & 1,454 & 241 \\
\hline Craftsmen, foremen and kin & dred w & orker & & & - & . & 386 & 153 \\
\hline Operatives and kindred worl & kers & - & . & & • & . & 1,340 & 732 \\
\hline Domestic service workers & • & $\cdot$ & . & & • & • & 1,407 & 1,187 \\
\hline Service workers, except dom & aestic & . & & & & . & 1,619 & 5,420 \\
\hline Farm laborers (wage worker & rs) and & farm & & emer & & & 4,916 & 13,767 \\
\hline Farm laborers (unpaid fam & ily wor & kers) & & . & . & & 1,462 & 23 \\
\hline Laborers, except farm & - & - & - & - & - & • & 2,493 & 626 \\
\hline Occupation not reported & $\cdot$ & - & . & - & - & & 137 & 66 \\
\hline & & & & & & & 208 & 2,961 \\
\hline
\end{tabular}

These statisties are taken from Tables 38 and 44 of the 16th Census of the United States: 1940, Characteristics of the Nonwhite Population.

35 The propensity of the ahen Japanese to become farmers may be gauged somewhat by what the unrestricted citizen Japanese do. Out of 17,207 American citizen Japanese fourteen years of age, and older, employed in California in 1940, in other than emergency work, there were 1,663 farmers and farm managers, 2,791 farm wage workers and foremen, and 2,497 unpaid family farm workers, totaling 6,951 , or 40.3 per cent. 16th Census of the United States: 1940, Characteristics of the Nonwhite Population, Table 38. The small number of farm owners among them may be partly due to the fact that their average age is much lower than that of the alien Japanese, resulting in lack of accumulated capital with which to buy land.

30 See 16th Census of the United States: 1940, Characteristics of the Nonwhite Population, Table 33.

40 Thomas and Nishmoto, The Spomage (1946) 2.

41 Ibid. at 4. 
aliens suffered heavy pecuniary losses incident to their evacuation during the war. Suddenly ordered to abandon their properties and their homes, many felt compelled to sell at sacrificial prices. Others lost through unfaithful custodianship of their properties during their absence. Confined to so-called relocation centers, they were cut off for nearly three years from any gainful enployment. The result is that many of the well-to-do among them returned to California broken in fortune, with very few years of life left for financial recuperation.

Thus we have arrived at the size and character of what many Californians still regard as their yellow peril. It is this shrunken, and rapidly shrinking, small number of aged Japanese aliens, their fortunes, of those who had them, much depleted, to whom the California law denies the acquisition of any mterest in agricultural land, and, probably, the ownership of any land for any purpose. Is it entirely irrelevant to add that many of these aged alien Japanese are the parents of American citizens who served in combat forces of the United States throughout the war and with marked distinction? Toward the end of the war a few alien Japanese were accepted as volunteers in the fighting forces, and all through the war many of them were eniployed by the War Department as language instructors, map readers, translators and in other capacities.

What is the size of the menace which threatens the welfare of the nine other states that have imitated California? The total number of Japanese aliens residing in all of those states in 1940 was 3,667. These states may, however, be retaining their "ineligible alien" land laws out of fear that some of the Japanese aliens now residing in other states may move into them. None can enter from abroad. The number residing at the present time in all the other states, including California, probably does not exceed 40,000 . What probability is there that any considerable number of these aged persons will remove from the comununities in which they have social and economic ties and settle in any single one of these nine states?

Judged by the number of Japanese aliens residing in any one of them, it takes a very prejudiced imagination to see a threat to a state's welfare. In no one of them can there be more than a handful of "ineligible aliens", other than Japanese, because there are now less than 853 residing in the continental United States. Arkansas, as we have seen, has a land law which discriminates exclusively against Japanese. In 1940 there were only two Japanese aliens among her total of 3,210 alien residents. 
The following table shows the size of the Japanese menace in each of the nine states:

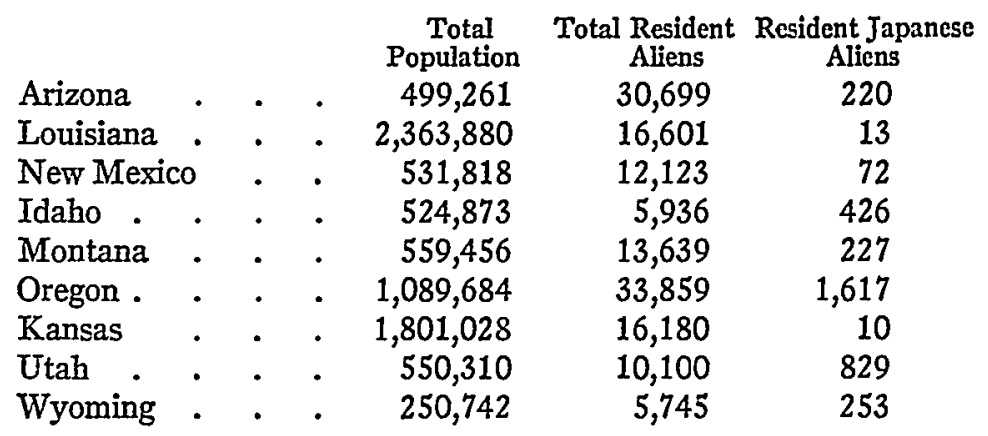

The constitutional issue is whether California can pick out of her half-million alien residents, 25,000 Japanese aliens, together with an almost imperceptible number of Korean, Malay, and Polynesian aliens, and deny rights to them that she concedes to all others. Can Kansas deny to her ten Japanese alien residents rights which she grants to sixteen thousand other alien residents? Does such discrimination bear any rational relation to any purpose within the competency of the state?

To show the extraordinary narrowness of the discrimination made by the "ineligible alien" land laws, I shall review the origin in AngloAmerican law of discrimination against aliens with respect to landholdings. I shall inquire whether the old common-law discrimination ever had any rational basis, although it was against all aliens without regard to race or national origin. I shall then review the law now in force in each of our states to determine what is the prevailing thought of our time with respect to the rationality of discrimination against any aliens with respect to land holdings.

\section{THE ENGLISH COMMON LAW WITH RESPECT TO LANDHOLDING BY ALIENS}

Under the common law as evolved by the end of the thirteenth century an alien could acquire goods and chattels in England, keep them, dispose of them, even by will, and if he died without a will his personalty went to his next of kin, even though they were aliens. Thus as to goods and chattels an alien stood on an equal footing with a subject of the King. But it was a different matter as to real property situated in England. An alien could not acquire such realty by inheritance. In the quaint language of the common law he lacked "inheritable blood". Nor could he acquire it by mere operation of law, but he could acquire it by act inter partes, as by gift to him, by 
sale to him, by devise, by lease, but he held it at the sufferance of the King, who might forfeit it to himself without compensation by the procedure called "inquest of office". And this at a time when all the King's property was his privately and not held in a governmental capacity in trust for the nation. The defeasible estate in realty which an alien might acquire he could convey to another. But the latter, alien or subject, in turn held it as a defeasible estate subject to forfeiture. If not transferred by the alien, at his death it escheated automatically to the King, for an alien was held to have no heirs.

The subtlety of the system! As Blackstone said, if an alien bought land from a subject the vendor could keep the price, for the conveyance was good to pass the vendor's title. ${ }^{42}$ The King would have had no benefit had the rule been that the conveyance was void. As it was the alien lost both money and land if the King enforced the forfeiture.

Historians of the law of England say in explanation of the origin of these rules that "in the course of the thirteenth century our kings acquired a habit of seizing the lands of Normans and other Frenchmen" because, as they said, the Normans were traitors and the Frenchmen enemies. To these historians it seems that the King's later claim of right to seize the lands of aliens generally is an exaggerated generalization of his claim to seize the lands of his French enemies. "Such an exaggerated generalization of a royal right will not seem strange to those who have studied the growth of the king's prerogatives." 43

After these rules had been established for two centuries Coke attempted to supply the reasons for them, both for seizures during war and during peace. During war, if aliens held land in England, " 1 . The secrets of the realm might thereby be discovered. 2 . The revenues of the realm (the sinews of war, and ornament of peace) should be taken by strangers born. 3 . It would tend to destruction of the realm." That destruction would consist in this, that "Strangers might fortify themselves in the heart of the realm" like "the Trojan horse in Vergil's Second Book of his Aeneid."

In time of peace the condition of England would be equally desperate, for, said Coke, so much of the freehold of England would be held by aliens that there would not be enough English freeholders to man the juries and hence "there should follow a failure of justice." 45

421 BI. Cosar. *372.

43 Poliock and MaItuand, History of English Law (2d ed. 1898) 463.

14 Calvin's Case (1609) 77 Eng. Rep. 377.

45 Ibid. 
It is to be noted that only the last reason is tied up with landholding, and that it is based on an absurd exaggeration. The other reasons all turn on the danger to the realm of having enemy aliens residing in England during war. They afford no adequate explanation why landholding alone should be denied to aliens, who were freely admitted to reside permanently in England, acquire and hold all other kinds of property, and engage in trade and all other pursuits on an equal footing with English subjects.

Wheaton, commenting upon similar early laws of other European countries, surmised that they originated during the regime of feudal tenures, with their incident of military service, when the notion was that the latter could be exacted only of subjects owing allegiance. ${ }^{\text {to }}$ Blackstone offered the same explanation: "The design of introducing our feuds, the defense of the kingdom, would have been defeated" if lands had been suffered to be held by persons who owed no allegiance to the King. ${ }^{4 \pi}$

Writing in 1853, Chief Justice Redfield of Vermont said, "The escheat of estates to the sovereign, in consequence of a conveyance to an alien, is a result of purely feudal character. It was so held, because an alien, owing a foreign allegiance, was regarded as incapable of performing feudal military services to the king, as lord paramount of all the land in the realm." 48

France abolished all discrimination against aliens with respect to holding real and personal property in 1819 and the British Parliament did so in 1870 .

In the meantime the common law's discrimination against aliens had been received in the British colomes in America. Since the colonies were independent of each other, tied together only by their common subjection to the central government of the empire, each had its separate body of law. But the anti-alien law of one colony did not apply to a British subject residing in another colony, or elsewhere; a British subject was not an alien in the law of any British colony. After the colonies became states, in theory independent of each other as well as of Great Britain, a provision was adopted in the Articles of Confederation to forbid any state to impose the disabilities of alienage upon the citizens of any other state. ${ }^{49}$ Our present

46 Wheaton, International Law (4th Eng. ed.) 134.

$4 \overline{2} 2$ BL. Comar. $* 250$.

48 State v. Boston, Concord \& Montreal R. R. Co. (1853) 25 Vt. 433, 438.

49 Art. IV. 
Constitution, as adopted in 1788, contains a like clause, for the same purpose: "The Citizens of each State shall be entitled to all Privileges and Immunities of Citizens in the several States." 50

Inasmuch as there was no other equalitarian clause in the Constitution prior to the equal protection clause of the Fourteenth Amendment, ratified in 1868, the states were free to enforce the common law's discrimination against aliens. The dates at which its partial or complete abolition first occurred in the several states I have not traced. It is sufficient for our purposes to examine the extent to which it is abolished or partially retained at the present time.

\section{STATE IAWS}

An examination of the constitutional and statutory law ${ }^{51}$ of the forty-eight states discloses that in sixteen states ${ }^{52}$ all aliens, whether residents of the United States or not, and whether friendly or enemy aliens, are given equal rights with citizens to acquire, hold, and dispose of real property. In three other states the law is the same except that there is a restriction as to the amount of land an alien may hold: in Indiana, ${ }^{53}$ not over three hundred and twenty acres; in Pennsylvania, ${ }^{54}$ not over five thousand acres; and in South Carolina, ${ }^{55}$ not over five hundred acres. As the permissible amounts are large there is slight distinction between these three states and the sixteen above

50 U. S. Const., art. IV, \$ 2, cl. 1.

51 For digests of the laws of all states made by other writers, see 5 VERNDER, AXIERICAN FanIILY LAws (1938) $\$ \$ 289,290$, which follows a different scheme of analysis, and necessarily omits subsequent legislation; Miller, Alien Land Laws (1939) 8 GEo. WASE. L. REv. 1, apparently based on VerNIER, loc. cit. sutpra.

12 Ala. Const. art. I, § 34; Ala. Code (1940) tit. 47, § 1; Colo. Const. art. II, § 27 ; Colo. Stat. (1935) c. 7, § 6; Dez. Rev. Code (1935) §\$ 3655-3657; Fla. Const., Declaration of Rights, § 18; FIA. STAT. (1941) § 731.28; ME. Rev. Stat. (1944) c. 154, § 2 ; Mass. Laws (1932) c. 184, § 1; Mrch. Const. art. XVI, § 9; MrCH. Comp. Laws (1929) $\S 13493$; N. Y. Real Property Latw (1945) § 10(2); N. C. Gen. Stat. (1943) § 64-1; N. D. REv. CODE 47-0111, 56-0116; OHIO CODE (Throckmorton, 1940) § 10503-13; R.I. Gean. Laws (1938) c. 432 ; S. D. Const. art. VI, §14; S. D. Cone (1939) §§51.0205, 56.0120; TENN. CODE (Williams, 1934) \$§ 7187-7190; VT. CoNst. (1793) c. II, §62; W. VA. CoNst. art. II, § 5; W. VA. CoDE (1943) §3541. The Vermont constitution of 1793 gave resident aliens equal rights with citizens in landholding, and while no other constitutional or statutory provision abolished the common-law rules with respect to nonresident aliens, the supreme court of the state held in 1853 that no procedure for the forieiture of the estates of aliens, resident or nonresident, was known to the law of the state. State v. Boston, Conrad \& Montreal R. R. Co., supra note 48. The present attorney general of Vermont assures me that that is still true.

53 Ind. STat. (Burns, 1943) \$§ 56-504, 56-505.

54 Pa. Stat. (Purdon, 1936) tit. 68, \$\$ 22-32.

55 S. C. Const. art. III, $\$ 35$; S. C. Code (1942) $\$ \$ 8687,8907,8908,7790$; S. C. Laws 1945, p. 51. 
mentioned. Four other states ${ }^{58}$ grant equality with citizens to all aliens except enemy aliens. This transient disability of an alien during a war between the United States and his country is a slight qualification of the general rule. Thus there are twenty-three states which with substantial accuracy may be said to have completely wiped out the common law's discrimination against aliens with respect to acquiring and holding real property. That these states have acted affirmatively to abolish it shows that in the judgment of their lawmakers no rational basis for its retention exists. It is significant that New York is in this group although one-fourth of all the aliens in the forty-eight states reside in New York. ${ }^{67}$.

In a twenty-fourth state, Wisconsin, the law is substantially the same. ${ }^{58}$ All aliens have equal rights with citizens to acquire and hold realty, except that the amount of land an alien not residing in the United States may acquire is limited to three hundred and twenty acres, unless acquired by devise, inheritance, or in the collection of debts. In Iowa, a twenty-fifth state, the law is almost exactly the same as in Wisconsin. ${ }^{59}$

Nine other states join the above twenty-five in putting all aliens, resident or nonresident, on an equality with citizens with respect to acquiring and holding realty, except aliens ineligible to naturalization under the laws of the United States. These, as we have seen, are California and her imitators, Arizona, Idaho, Kansas, Louisiana, Montana, New Mexico, Oregon, and Utah. That is to say, the very states that discriminate against particular races or nationalities of aliens concede to aliens generally, whether resident or nonresident, equality with citizens in acquiring and holding realty, with only slight exceptions in Arizona ${ }^{60}$ and Montana ${ }^{61}$ with respect to acqui-

56 Ga. Code (1933) § 79-303; MD. Code (Flack, 1939) art. 3, § 1; N. J. Rev. Stat. (Supp., 1941-1944) 46: 3-18 (not all enemy aliens are excepted, since the denial does not extend to enemy aliens who have permanent residence in the United States and are licensed or permitted by the federal government to engage in business transactions and are not under arrest or interned); VA. CoDE (1936) § 66.

57 REe. ATT'y GeN. 1941, at 259.

58 WIs. STATs. (1943) §§ 234.22, 234.23.

59 A curious and slight difference is that in Iowa if a nonresident alien acquires land by devise from any alien or any naturalized citizen, he must dispose of it within twenty years, or become a citizen within that time. Tows CODE (1946) $\$ 567.1$.

${ }^{60}$ An alien, other than an "inehgible alien", who acquires realty by devise or descent may hold it only five years, unless he becomes a citizen, saving, however, greater rights if the law of his country gives greater rights to American citizens. ArIz. CoDz (1939) § 39-111.

61 An alien, other than an "ineligible ahen", may take property in Montana by will 
sitions by will or intestacy. Arkansas increases this group to ten for she also has the general rule of equal rights of aliens and citizens in landholding with the sole exception of nonresident Japanese aliens, and this exception will fall if the state supreme court holds the statute of 1943 void as a whole.

Thus there are thirty-five states that now see no virtue whatever in the common law's discrimination against aliens, except that ten of them retain something like the common-law system with respect to a small minority of aliens. Their narrow racial discrimination is an exception to a general policy of putting aliens, both resident and nonresident, upon an equal footing with citizens.

Five other states have abolished the common law with respect to all resident aliens, while retaining it more or less intact with respect to nonresident aliens. That is, all resident aliens are put on an equal footing with citizens with respect to acquiring and holding realty. These states are Connecticut, Mississippi, New Hampshire, Oklahoma, and Wyoming. ${ }^{62}$ It should be noted that Connecticut gives such equal rights not only to aliens residing in the state but also to aliens who reside anywhere in the United States, barring only those who reside in foreign countries.

One other state, Minnesota, also accords substantial landholding rights to aliens, resident and nonresident, although the amount that may be held is restricted. Any alien, resident or nonresident, may hold land acquired by devise or by inheritance without limitation as to amount, but only 90,000 square feet, or about two acres, if the mode of acquisition is other than devise or inheritance. More pertinent to this article is the privilege Minnesota gives resident aliens to own farm lands. An alien may acquire a farm for his own occupancy by any mode known to the law and hold one hundred and sixty acres. ${ }^{63}$ Thus resident aliens are encouraged to engage in agriculture in Minnesota. Moreover, there is no restriction whatever on an alien who has declared his intention to become a citizen.

In summary so far, it appears that while many states give all aliens, resident or nonresident, equal rights with citizens in landhold-

or by intestacy only to the extent that his country permits residents of the United States to so take property left by decedents in that country. Mont. Laws 1939, p. 220.

62 Conn. Gen. Stat. (1930) §5055; Miss. Code (1942) §842; N. H. Rev. Laws (1942) c. 259, § 19; OKLA. Const. art. XXII, § 1; OKIA. Stat. (1941) tit. 60, §§ 121-127; WYo. Const. art. I, $\S 29$; see supra p. 8 for a discussion of the Wyoming statute and constitution.

63 MINN. StaTs. (1941) §500.22. 
ing, there are forty-one states that do so with respect to resident aliens, with the following exceptions: (1) four of them ${ }^{64}$ limit the amount of land an alien may hold but nevertheless permit large holdings; (2) four of them ${ }^{65}$ make a slight exception of enemy aliens; (3) nine of them ${ }^{66}$ deny such equality to none but that small minority that consists of aliens racially ineligible to naturalization; and (4) one ${ }^{c \tau}$ denies such equality solely to nonresident Japanese aliens. There remain only seven states in which the law approximates the common-law system with respect to both resident and nonresident aliens, but in none is that system preserved intact, although in a few the departures are slight. The remaining states are Illinois, Kentucky, Missouri, Nebraska, Nevada, Texas, and Washington. In Kentucky, Texas, and Washington the restrictions apply to both resident and nonresident aliens although an exception is made in favor of resident aliens who have declared their intentions to become citizens. In Texas there is the further remarkable exception that the law does not apply to aliens who are natural-born citizens of countries that have a common land boundary with the United States. It seems that Canadian and Mexican born aliens as landholders in Texas do not threaten the welfare of the state, but that aliens born elsewhere do. The law of the state of Washington will be stated more fully in the text when we come to consider the decision of the Supreme Court of the United States holding it not unconstitutional. The similarities to and departures from the common law in the other six states in this group are set forth in Appendix B.

\section{ALIENS' PROPERTY RIGHTS IN CALIFORNIA PRIOR TO 1913}

Under her first constitution (1849) California gave to resident aliens of every race and nationality a constitutional guaranty that they should enjoy complete equality of property rights with citizens.

Article I (Declaration of Rights) contained: "Section 17. Foreigners who are, or may hereafter become, bona fide residents of this State, shall enjoy the same rights in respect to the possession, enjoyment, and inheritance of property, as native born citizens."

This constitutional guaranty was cut down in the constitution of

64 Indiana, Pennsylvania, South Carokina (stepra notes 53-55), and Minnesota (supra note 63).

65 Supra note 56.

66 Supra notes 2, 3, 5-12.

${ }^{67}$ Supra notes 16, 17.

68 Cal. Stats. 1849-1850, p. 25. 
1879 to protect only white and Negro resident aliens: "Section 17. Foreigners of the white race or of African descent, eligible to become citizens of the United States under the naturalization laws thereof, while bona fide residents of this State, shall have the same rights in respect to the acquisition, possession, enjoyment, transmission, and inheritance of property as native-born citizens." ${ }^{28}$

By amendment, adopted November 6, 1894, this constitutional guaranty was further cut down to cover only property "other than real estate". . $^{\text {. }}$

I have emphasized that these were constitutional guaranties and thus affirmative grants of minimum rights which the legislature was forbidden to deny. They did not operate negatively to preclude the legislature from granting equal rights to other aliens or broader property rights to all aliens. In fact, these constitutional guaranties at no time defined the property rights of aliens in California. These rights were defined in section 671 of the Civil Code of 1872 which, after slight amendment in $1874,{ }^{71}$ read as follows: "Any person, whether citizen or alien, may take, hold, and dispose of property, real and personal, within this State."

This code section embodied the most liberal policy with respect to the property rights of aliens. It granted to all aliens irrespective of race or nationality, irrespective of residence or nonresidence, ${ }^{\text {i2 }}$ equality with citizens in the acquisition and holding of property of every kind. The supreme court of California has many times held that this broad grant is in nowise in conflict with the minimum guaranties of the state constitution. ${ }^{73}$ This code section continued in force after the constitution of 1879 was adopted, and indeed, has never been repealed. It is still the law of California with respect to all aliens except those ineligible to naturalization, first discriminated against by the statute of 1913 . That discrimination is contained in the law now in force, the scope of which is next to be stated.

\section{RIGHTS DENIED TO "INELIGIBLE ALIENS" BY PRESENT CALIFORNIA LAW}

California's "ineligible alien" property law from its beginning in

69 Cal. Stats. 1881, xxiv.

70 Ibid. 1895, xxxii.

11 Cal. Acts 1873-74, p. 218, which inserted the words, "and dispose of".

72 Blythe v. Hinckley (1900) 127 Cal. 431, 59 Pac. 787; Estate of Pendergast (1904) 143 Cal. 135, 76 Pac. 962.

73 Estate of Billings (1884) 65 Cal. 593, 4 Pac. 639; State v. Smith (1886) 70 Cal. 153, 12 Pac. 121; and cases cited supra note 72. 
1913 has expressed itself in a "backhanded fashion". "4 Sections 1 and 2 of the Initiative Act of 1920, slightly amended in 1923, contain the more fundamental provisions now in force. ${ }^{75}$ Section 1 affirmatively grants to aliens eligible to naturalization rights equal to those of citizens of the United States to "acquire, possess, enjoy, use, cultivate, occupy, transfer, transmit and inherit real property, or any interest therein, in this state, and have in whole or in paft the beneficial use thereof." Section 2 proceeds, affirmatively also, to grant to "all aliens other than those mentioned in Section one" the same all inclusive rights with respect to real property "in the manner and to the extent, and for the purposes prescribed by any treaty now existing between the government of the United States and the nation or country of which such alien is a citizen or subject, and not otherwise." (Emphasis added.) The last phrase is the negating bite of the statute. In effect the two sections declare that an alien ineligible to naturalization shall have no rights whatsoever with respect to "real property" in California other than those secured to him by a "now existing treaty" between the United States and his country, while all other aliens shall have the saine rights as citizens.

The statute does not mention agricultural land specifically. Its denials are with respect to "real property" in general and of "any interest therem" and of "any beneficial use thereof", subject to then existing treaty rights. The expression "treaty now existing" was used in the statute of 1913 , the Initiative Act of 1920 , and in the statute of 1923, amending the latter, and is the wording of the law at the present time. The only treaty between Japan and the United States in those years was that of $1911,{ }^{76}$ and it was abrogated by the United States in 1940. ${ }^{77}$ A California district court of appeal has held ${ }^{73}$ that the abrogation of the treaty is of no significance, on the ground that its provisions were incorporated into the statute by the words "treaty now existing". The abrogation, however, has very substantial effect upon the law in several other of the "ineligible alien" land law states: those whose statutes made no reservation of "now existing treaty"

74 Powell, Alien Land Law Cases (1924) 12 CaLrF. L. Rev. 259, 262.

T5 The law now in force is compiled in CaL. Gen. LAws, Act 261.

7837 STAT. (1911) 1504.

77 On July 26, 1939, the United States served formal notice on the Government of Japan terminating the treaty six months from that date, i.e., on January 26, 1940. Dept. of State Bull. (July 29, 1939) vol. I, p. 81.

78 Palermo v. Stockton Theatres, Inc. (1946) 76 A. C. A. 26, 172 P. (2d) 103, hearing granted (Oct. 31, 1946). 
rights. ${ }^{79}$ In them Japanese nationals now unprotected by any treaty have no rights whatsoever with respect to realty-if the laws are valid.

If the above interpretation of the California law is correct, its negation of rights im real property to the Japanese is still qualified by the provisions of the abrogated treaty, just as it was qualified while the treaty was in force. By the treaty, Japanese nationals in the United States and American citizens in Japan were secured, so far as real property is concerned, rights "to own or lease and occupy houses, manufactories, warehouses and shops, . . . to lease land for residential and commercial purposes ...."

"It will be noted," said the recent Attorney General of Califorma, "that the right to own land, for any purpose, is nowhere reserved." so He further said, "The escheat program now in progress [1944] is directed primarily at agricultural lands, at least for the present. This does not inean, however, that ownership of land for other uses and purposes will not be made the subject of scrutiny and action later on ...." "s1

According to this interpretation Japanese aliens can own or lease buildings for commercial and residential purposes, but can merely lease, not own, the land on which the buildings stand. Whether or not this is in accordance with the liberal construction which the Supreme Court of the United States holds should be given treaties, it may be a different question as to the interpretation of an abrogated treaty, the provisions of which merely survive as a part of a state statute into which they are incorporated by reference.

While the treaty with Japan reserved to Japanese aliens at least the right to own certain kinds of buildings and to lease land for commercial and residential purposes, even these rights are denied to "ineligible aliens" who are nationals of countries with whom the United States did not have at the crucial dates, and does not now have, any protective treaty. ${ }^{82}$ No doubt the latter is an inadvertent effect of the law, its promoters being absorbed in curtailing the rights of Japanese aliens so far as the treaty with Japan permitted.

70 Louisiana, New Mexico, Montana, and Wyoming, supra notes 6, 7, 9, 13.

80 Robert W. Kenny, Attorney General of California, in a public address. Proceedings of the Cahifornia Land Title Association, Thirty-eighth Annual Conference, June 7 and 8, 1944, Pasadena, California, pp. 91-101 [reprinted in Brief for Respondent, App. p. 6, People v. Oyama (1946) 29 A. C. 157,173 P. (2d) 749.]

81 Ibid.

82 Limits of time have prevented investigation of the suggested question. 
There has never been any question but that the treaty with Japan secured no rights to her nationals with respect to holding agricultural land, and while the statute of 1913 permitted "ineligible aliens" to "lease lands in this state for agricultural purposes for a term not exceeding three years", this privilege has been denied since the Initiative Act of 1920. Substantially all criminal prosecutions and escheat proceedings under the California law to date have presented issues with respect to the acquiring of some interest in agricultural lands by Japanese aliens. The advocates and defenders of the law have always emphasized that it kept the farm lands out of the hands of "ineligible aliens", particularly the Japanese. How far its terms do forbid farming by "ineligible aliens" is worth examination.

The strongest words of the law are those forbidding the proscribed class from acquiring "any interest" in real property or having "in whole or in part the beneficial use thereof." Since 1923 the law has also forbidden a member of the class from farming land under a crop-sharing contract, although technically such a contract confers no legal interest in the land. How this feature came into the law is interesting but is consigned to a footnote. ${ }^{83}$

The law, however, does not, and does not purport to, keep Japanese or other "ineligible aliens" off the farms of California. Any owner inay hire an alien Japanese as farm-manager for wages other than a share in the crop. Any owner may employ Japanese aliens as farm laborers, including foremen. Indeed some proponents of the law de-

83 The Initiative Act of 1920 (Cal. Stats. 1921, p. loxiii) did no more than prohibit the acquisition of "an interest" in real property. United States District Judge Dooling held in 1921 that "the cropper has no interest in the land, merely receiving his share of the crop as the price of his labor." O'Brien v. Webb (1921) 279 Fed. 117, 119. Nevertheless he assumed in a dictum "that the state has the power to inhibit an alien inadmissible to citizenship from making a contract to farm on shares ... ." Ibid. at 124. On June 28, 1923, the supreme court of California also held that the Act of 1920 did not forbid crop-sharing contracts. In re Okahara (1923) 191 Cal. 353, 216 Pac. 614. Judge Dooling's decision was reversed by the Supreme Court of the United States (Nov. 19, 1923) on the ground that while such a contract gave no legal interest in the land it gave "use, control, and benefit of land . . . substantially similar to that granted to a lessee." Webb. v. O'Brien (1923) 263 U.S. 313, 324. The Court further held that the statute so construed was not unconstitutional. It had some difficulty in distinguishing the cropping contract before it from that in the California case above cited. The supreme court of California immediately revised its interpretation of the Act of 1920, accepting the United States Supreme Court's interpretation. Porterfield v. Webb (1924) 195 Cal. 71, 231 Pac. 554. In the meantime the California legislature, encouraged perhaps by the dictum of Judge Dooling, expressly declared that cropping contracts were within the prohibitions of the Act (Cal. Stats. 1923, p. 1023) and also amended section 2, to insert the words, "have in whole or in part the beneficial use" of real property. (Ibid., p. 1021.). 
sired Japanese farm workers and welcomed the reduction of the alien Japanese agriculturists to that status. Moreover, the law did not completely wipe out farm ownership by "meligible aliens". It did not attempt to escheat farm lands owned by them before the statute of 1913 became effective, although further performance of executory contracts by which they were entitled to acquire land was held to be illegal. ${ }^{84}$ Thus the Census of 1940 , in reporting the occupations of persons fourteen years old and older, shows that over ten thousand alien Japanese were engaged in farming in California: ${ }^{85}$

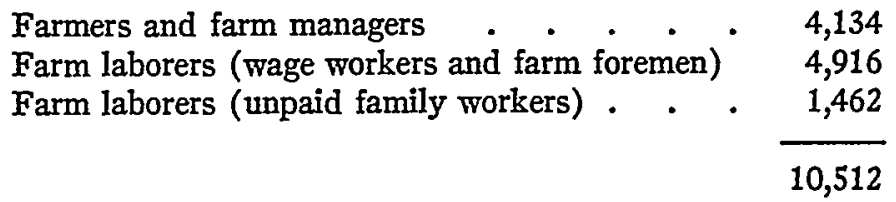

Japanese aliens in California may be farm managers, not only for hire, but as legally appointed guardians of estates including farm lands, despite the attempt in the Initiative Act of 1920 to forbid the appointment of any "ineligible alien" as "guardian of that portion of the estate of a minor" which consisted of real property that the "ineligible alien" could not himself legally acquire. ${ }^{86}$ In Estate of $Y a n 0^{87}$ a Japanese alien applied for appointment as guardian of the estate of his daughter, about three years of age, who was an American-born citizen, the estate consisting of fourteen acres of farm land. The superior court refused the appointment but was reversed by the suprene court of California. "It is settled law in this State," said the court, "that the father of a minor under the age of fourteen years is entitled as a matter of right ... to the guardianship of such minor, unless shown to be incompetent." 88 The court then held that the attempt of the statute to make "ineligible aliens" incompetent was an irrational discrimination and therefore a denial of equal protection of the laws both to the alien parent and to his citizen child.

Later it was held that the law does not nullify a bona fide transaction by which an "ineligible alien" supplies the money to purchase land as a gift to a citizen or any other person who is not an "ineligi-

84: See Mott v. Cline (1927) 200 Cal. 434, 253 Pac. 718; Delta Farms v. Chinese American Farms (1929) 207 Cal. 298, 278 Pac. 227.

85 16th Census of the United States: 1940, Characteristics of the Nonwhite Population, Table 38.

86 Cal. Stats. 1921, p. Ixxiii.

87 (1922) 188 Cal. 645, 205 Pac. 995.

88 Ibid. at 648, 206 Pac. at 997. 
ble alien", even though the grantee is the alien's minor child over whose estate the alien is entitled to be appointed guardian. ${ }^{80}$ There is, however, a statutory "prima facie presumption" that where payment is by an "ineligible alien" and title is taken in another's name the transaction is not bona fide and is illegal."0

Amendments to the law in 1923 and 1943 have added several provisions $^{91}$ to prevent an "ineligible alien" appointed as guardian of his American-born minor child "or as guardian of any other person" from using his guardianship as a cloak for evasion of the law. Such guardian is required to administer the estate "solely for the use and benefit of the ward", and is not to receive directly or indirectly any of the proceeds of the estate for his own use. While he may be compensated, the court supervising the guardianship is given power to fix the amount, and also to fix the amount of the guardian's bond, without any statutory standard being prescribed to control the court's discretion. The guardian is required to make detailed annual reports of receipts and disbursements and such additional special reports from time to time as the court may require.

Complying with all the statutory requirements, an "ineligible alien" may lawfully be the manager of a farm which is owned by a ward of whom he is the guardian, and the recent Attorney General of California, after intensive investigation, said, "It is not inferred that all cases of Japanese ownership following the guardianship pattern are spurious ...."

The procedures prescribed for enforcement of the law are: (1) escheat proceedings; $;^{93}$ (2) criminal prosecutions; ${ }^{24}$ and (3) injunction proceedings. ${ }^{.5}$ Prior to 1923, if an "ineligible alien" acquired a forbidden interest in real property and before escheat proceedings were begun sold it to any person legally competent to hold it, the latter acquired a good title. ${ }^{96}$ In that year, however, the law was amended to make the escheat occur at the date of acquisition by the "ineligible alien", with the consequence that a transfer by him before

89 People v. Fujita (1932) 215 Cal. 166, 8 P. (2d) 1011.

00 This provision was held not to be a denial of due process of law in criminal trials [Cockrill v. California (1925) 268 U.S. 258] nor in civil trials [Haruko Takeuchi v. Schnuuck (1929) 206 Cal. 782, 276 Pac. 345].

91 Car. Gen. Laws, Act 261, 84.

92 Op. cit. supra note 80, at 14.

93 Car. Grn. Laws, Act 261, $\$ \S 7,7.5,8,9$.

94 Ibid. § 10a.

95 Ibid. \$§ 10b, $11 \mathrm{a}$.

98 Mott v. Cline, supra note 84. 
the state acts gives the transferee no title. Where the interest acquired by an "ineligible alien" is a fee, whether it is held by him or by a transferee, it may be seized by the state and sold at public auction for the benefit of the state. Where the alien acquires a leasehold, or where he has a crop-sharing contract, not'only does his interest escheat, but also whatever interest the landlord has in the land escheats, whether it be a fee or a leasehold, and even though he is an "eligible alien" or a citizen, competent to hold land. The interests of both the "ineligible alien" and of the landlord are sold for the benefit of the state. No detail is overlooked.

When the 1923 amendment became operative, escheats in a sense became automatic, that is, by mere operation of law, although, to be sure, some proceeding by the state was necessary to establish the fact of violation and dispossess the holder of the escheated interest. But what of such escheats that may have occurred as long ago as 1924 and are not yet uncovered? The legislature in 1945 was greatly concerned lest proceedings to uncover them were barred by statutes of limitations, and in consequence amended the law to provide that "No statute of limitation shall apply or operate as a bar to any escheat action or proceeding now pending or hereafter commenced . . . "97 In what was perhaps a vain attempt to make this retroactive legislation appear not unconstitutional the amending statute declares that it "does not constitute a change $\mathrm{m}$, but is declaratory of the preexisting law." $" 98$

At the same session of the legislature a special appropriation of $\$ 200,000$ was made to the attorney general for the investigation of possible evasions of the law. Moreover, to stimulate local interest in discovering facts justifying escheat, the statute was amended to give the county in which escheated land lies one-half of the proceeds of the sale.99

Such expenditures and painstaking legislation to root out an evil that threatens the welfare of California is highly commendable. It is of course probable that some of the small group of aged Japanese aliens in California are holding interests in real property forbidden by the law.

Prior to 1943 the only criminal offense under the law was a conspiracy of two or more persons to violate it. ${ }^{100}$ Difficulty was encoun-

97 Cal. Stats. 1945, p. 2177 (§ 1).

98 Ibid. § 2.

Or Ibid. p. 2165.

100 Amendment of 1923, Cal. Stats. 1923, p. 1024. 
tered in proving a conspiracy, particularly in cases where the alleged transfer to the alleged "ineligible alien" was by a white American citizen, one of the alleged conspirators. Statutory presumptions of the existence of some of the facts essential to establish guilt were enacted, ${ }^{101}$ one of which was held unconstitutional by the Supreme Court of the United States. ${ }^{102}$ In 1943 the criminal conspiracy provisions were repealed, and instead the act of any individual violating "any provision" of the act was made a crime, with a possible punishment of ten years in a penitentiary and a fine of $\$ 5,000 .^{103}$ Under the old common law the holding of real property by an alien was never a criminal offense.

We pass now to less well-known features of the law, those prohibiting certain corporations from acquiring interests in real property in California. ${ }^{104}$

The provision with respect to corporations is an affirmative grant to every corporation whatsoever, whether "organized under the laws of this state or any other state or nation", of equal rights with a citizen in acquiring and holding real property in Califorma, without limit, with the single exception which denies such rights to a corporation "of which a majority of the nuembers" are "ineligible aliens" "or in which a majority of the issued capital stock is owned by such aliens." Thus even a corporation formed under the laws of Japan may hold real property without limit in California if, for example, Chinese nationals are dominant as shareholders both in number and value of issued stock. It is apparent that California has no policy agamst corporate landholding, either with respect to domestic corporations or foreigu corporations, using the latter tern in its broadest sense.

No doubt this discriminatory provision against particular corporations because of the race of their shareholders is valid, if the Supreme Court of the United States continues to hold valid the other portions of the law directed at individual "ineligible aliens", inasmuch as the provision operates to prevent the latter from accomplish-

101 Cal. Stats. 1927 , p. 881 ; Cat. Gew. Laws, Act 261 , $\S 9 \mathrm{a}, 9 \mathrm{~b}$.

102 Morrison v. California (1934) 291 U.S. 82. See Note (1934) 22 CaLrF. L. REv. 420.

103 "Any person who violates any of the provisions of this act [the basic act of 1921, as amended] shall be punishable by imprisonment in the county jail not to excced one year or im the State penitentiary not exceeding 10 years, or by a fine not to exceed five thousand dollars $(\$ 5,000)$, or both." Cal. Stats. 1943, p. 3002.

104 Cax. Gen. Laws, Act 261, §3. 
ing forbidden objectives by incorporation. Realty held by a corporation that has the proscribed shareholdership escheats to the state. ${ }^{105}$ By the terms of the law this may happen even with respect to a corporation which acquires land while all its shares are held by citizens or eligible aliens if "ineligible aliens" subsequently acquire the forbidden amount of shares, even though a remainder of the shares is still held by innocent shareholders who did not participate in the transfer to "ineligible aliens".

The restriction with respect to corporations is expressly subject to "now existing" treaty rights. Thus it has been held that the treaty right of individual Japanese nationals "to lease land ... for commercial purposes, and generally do anything incident or necessary for trade upon the same terms as native citizens" gives alien Japanese the right to incorporate under Califormia law for the purpose of leasing land upon which to operate a lospital as a business enterprise. $^{100}$

In addition to the provision that a corporation's realty escheats if "ineligible aliens" are dommant in shareholding, there is a further provision that a simgle share acquired by an "ineligible alien" also escheats, if it is a share in any corporation authorized to acquire real property, ${ }^{105}$ (and rare is the corporation that is not) unless the corporation is authorized to acquire no other interest in real property than such as an individual "ineligible alien" may acquire by a "now existing treaty". Thus it seems that a Japanese alien may not own a single share of stock in any corporation that is authorized to own land for any purpose, whether it is engaged in banking, insurance, retail trade, or any other business. But it seems that a Japanese alien may hold shares in a corporation authorized only to lease land, if its land is all held under a lease, and its corporate purposes are commercial, though not so if its leased land is held for agricultural purposes.

So thoroughgoing were the draftsmen of the California law that they regarded a share in a corporation as giving the shareholder a legal interest in the real property owned by the corporation, a peculiar instance of disregarding the separate corporate entity. They saw a menace to the welfare of California in a single "ineligible alien's" holding a single share in a corporation which owns land. What ra-

105 Ibid. \&7.

${ }^{108}$ Tashiro v. Jordan (1927) 201 Cal. 236, 256 Pac. 545, aff'd in Jordan v. Tashiro (1928) 278 U.S. 123.

10 T Cat. Gen. Laws, Act 261, $\$ 8$. 
tional relation to what purpose has this discrimination which forbids an alien of particular racial blood or particular mixtures of racial blood to acquire a single share of stock in particular corporations, while aliens of other bloods or mixtures may acquire shares in the same corporations without restriction? Nevertheless the Supreme Court of the United States in 1923 held this feature of the law to be not unconstitutional. ${ }^{108}$ It also held that a Japanese alien had no treaty right to acquire shares in a corporation that owned agricultural land.

Not only does a share of stock acquired in violation of the law escheat to the state but the alien violator is subject to the heavy criminal penalties prescribed by the law. ${ }^{100}$

In summary, the California law forbids Japanese aliens to hold any legal interest in land, except a leasehold for commercial and residential purposes, and the concept of a legal interest in land is stretched to include the holding of a share in a corporation that is authorized to own land, or that leases land for purposes not commercial within the meaning of the treaty, and is also stretched to include a sharecropper's contract of employment on farm land.

With respect to "ineligible aliens" who are nationals of countries that have no protective treaty with the United States, they may not acquire any kind of interest whatsoever in real property in California, nor hold a single share of stock in any corporation authorized to acquire real property in California for any purpose.

Thus while the California law is often defended as one that reserves the agricultural land for citizens, it does not do so because all the aliens in the world other than "ineligible aliens" may acquire agricultural land in California without limit, either as individuals or under corporate orgamization, and, moreover, the law's restrictions are not confined to interests in agricultural land.

\section{THE CONSTITUTIONAI QUESTION}

In 1923 the Supreme Court of the United States, in three cases, held that the California Initiative Act of 1920 was not unconstitutional, so far as it was not in conflict with any treaty, in denying to "ineligible alien" residents of the state, but to no other residents: (1) acquisition of any interest in real property in the state; ${ }^{110}$

108 Frick v. Webb (1923) 263 U.S. 326.

109 Supra note 103.

110 Porterfield v. Webb (1923) 263 U.S. 225, af'g (1921) 279 Fed. 114. 
the farming of land under a crop-sharing contract; in and (3) the holding of a share of stock in any corporation authorized to hold real property. ${ }^{112}$ All three of these cases reached the Supreme Court through the lower federal courts ${ }^{113}$ and the supreme court of California had not passed upon the constitutionality of any of the above provisions. ${ }^{114}$ In 1922 the latter court held that the guardianship provision of the act was unconstitutional as a demal of equal protection of the laws to "ineligible aliens". 115

The Supreme Court of the United States is the authoritative decider of issues arising under the Constitution of the United States. Anyone who believes that it has committed error in decision should remain silent or give very cogent reasons for his disagreement. The burden of persuasion is a heavy one, and the attempt to discharge it here may exhaust the patience of the reader. The charge I make, however, is not the graver one that the Court mismterpreted the Constitution. The charge is that without amrouncing any novel doctrine of constitutional law, the Court misapplied a settled interpretation through failure to appreciate the peculiarities of the legislation it was considering. The reader will please keep that distinction in mind throughout the following discussion.

Every state law that discriminates against a particular class of residents must run the gauntlet of the Fourteenth Amendment's limitation: "No State shall ... deny to any person within its jurisdiction the equal protection of the laws." Those words clearly embrace every resident of a state.

It is settled by Supreme Court decision that resident aliens as a class and as individuals are entitled to "equal protection"116 as well

111 Webb. v. O'Brien (1923) 263 U.S. 313, rev'g (1921) 279 Fed. 117.

112 Frick v. Webb (1923) 263 U.S. 326, af'g (1922) 281 Fed. 407.

113. Supra notes 110-112.

114 In 1922 the supreme court of Calitornia, after stating that no constitutional issue bad been raised in the case [In re. Akado (1922) 188 Cal. 739, 743, 207 Pac. 245, 246] said: "It is well settled that, in the absence of a treaty to the contrary, a state may forbid the taking or holding of property within their [sic] limits by aliens. (Blythe v. Hinckley, 127 Cal. 436)." Neither the dictuin nor the case cited to support it touched at all the issue whether a state may set "ineligible alien" residents apart and deny to them rights which it concedes to all other residents. Indeed the cited case does not support the proposition that a state may deny to any alien the acquisition of realty. What it held was that a statute of California was valid insofar as it conferred upon a Brilish national, not residing in California, the right to inherit California land and that such a statute did not invade the treaty power of the national government.

115 Estate of Yano, supra note 87.

116 Yick Wo v. Hopkins (1886) 118 U. S. 356; Truax v. Raich (1915) 239 U.S. 33. 
as all other classes of residents. The expression "any person" in the clause was too clear to permit any other construction. Moreover, congressional legislation immediately after the ratification of the Fourteenth Amendment, enacted in furtherance of its provisions, discloses that the contemporary Congress understood that the equal protection clause extends to alien residents. Thus the Civil Rights Act of May 31,1870, made it a criminal offense for any person "under color of any law" to deprive "any inhabitant of any State" of certam rights "on account of such person being an alien, or by reason of his color or race."117 Moreover, it declared that no state should levy any tax on "any person immigrating thereto from a foreign country" that it did not impose equally upon immigrants from other countries. ${ }^{118}$ Thus Congress assumed that the clause required states not to discriminate between aliens inter se-not to discriminate between the nationals of one foreign country and the nationals of another.

What is the "equal protection" that states are forbidden to deny to residents, aliens and all others? The Supreme Court's interpretation, which has been settled for at least fifty years, ${ }^{110}$ is that no state shall make any discrimination against alien residents or any other class of residents that is not rational with respect to the purpose of

11716 STAT. (1870) 140, 144.

118 Ibid.

119 The "rational basis" test was formulated at least as early as 1897 in Gulf, Colorado \& Santa Fe Ry. Co. v. Ellis (1897) 165 U.S. 150. As there expressed, the equal protection clause does not "withhold from States the power of classification ... yet it is equally true that such classification cannot be made arbitrarily." Classification "must always rest upon some difference which bears a reasonable and just relation to the act in respect to which the classification is proposed, and can never be made arbitrarily and without any such basis." Ibid. at 155. It seems that the Court's meaning would have been clearer if it had used the word "discrimination" where it used "classification". Usually classifications are not made by legislatures, but known and accepted classifications are made use of for statutory purposes. Thus the Court says, "The State may not say that all white men shall be subjected to the payment of the attorney's fees of parties successfully suing them and all black men not. It may not say that all men beyond a certaim age shall be alone thus subjected, nor all men possessed of a certain wealth. These are distinctions which do not furnish any proper basis for the attempted classification" [discrimination]. Ibid. at 155. In Clarke v. Deckebach (1927) 274 U.S. 392, 396, Justice Stone said, "Although the Fourteenth Amendment has been held to prohibit plainly irrational discrimination against aliens ... it does not follow that alien race and allegiance may not bear in some instances such a relation to a legitimate object of legislation as to be made the basis of a permitted classification" [discrimination]. It is true of course that an "invidious discrimimation" made by a statute sometimes consists in arbitrary definition of the class given "special treatment", as in Skinner v. Oklahoma (1942) 316 U.S. 535, so that the two expressions, "arbitrary classification" and "arbitrary discrimination" are equally applicable. 
the particular statute by which it is made. Not all state discriminatory laws are unconstitutional, for a class of persons may be singled out for different treatment provided the characteristics which distinguish the class rationally justify the difference in treatment.

Thus, a state statute which has for its purpose protection of the public health may prescribe qualifications of persons permitted to practice medicine, and exclude all others, provided the practice of medicine by persons lacking those qualifications may rationally be said to threaten the public health. If a state should prescribe citizenship as a qualification, the constitutional issue would be whether there is any rational ground for believing that alienage of a medical practitioner makes it likely that he will do acts prejudicial to public health, or in fact be less competent than citizen practitioners. Consequently, the purpose of a statute is a big factor in determining the constitutionality of any discrimination made by it against any particular class of persons. The irrationality or unreasonableness of a statutory discrimination is not tested in the abstract. Unreasonableness is always relative, and here it is a relation between the discrimination made by a statute and the purpose of the statute.

Had the Supreme Court held unconstitutional a state law which denies to all resident ${ }^{120}$ aliens, regardless of race or national origin, the privilege of acquiring real property, on the ground that such a discrimination against resident aliens has no rational relation to the protection of the health, safety, morals, or general welfare of the inhabitants of the state, what fault could be found with that application of the equal protection clause? That question in effect is whether after the ratification of the Fourteenth Amendment in 1868, any state could constitutionally enforce the old common-law rules against resident aliens. It is true that the due process of law clauses have been construed "not to overthrow ancient practices even when hard to reconcile with justice", as Justice Holmes said, ${ }^{121}$ but such leniency on the part of the Court in applying the vague requirement of "due" or proper procedure, a requirement which itself is rooted in history, seeins inapplicable to the much more specific requirement of equality

120 To the extent that the common-law rules operated against nonresident aliens, no question of the constitutionality of a state's adopting them would arise under the equal protection clause since it does not extend to persons not within the state's jurisdiction.

121 Power Co. v. Saunders (1927) 274 U.S. 490, 498, doubtless referring to the decisions in Murray v. Hoboken Land Co. (1856) 59 U.S. (18 How.) 272, and Ownbey v. Morgan (1921) 256 U.S. 94. 
with respect to all persons within a state's jurisdiction, which obviously was intended to be innovational.

No case questioning the power of a state to enforce the commonlaw rules against alien landholding after the adoption of the Fourteenth Amendment came to the Supreme Court before 1923. All that it had said on the point in the meantime had been dicta. ${ }^{122}$ The question was raised in 1923 in Terrace v. Thompson, ${ }^{123}$ in which the Court sustamed the alien land law of the state of Washington. The Washington law denied the right to hold land in the state to all aliens whatsoever, resident and nonresident, except "an alien who has in good faith declared his intention to become a citizen of the United States."124 The exception was the only substantial deviation from the common law, and was argued by counsel and discussed by the Court as the possible ground for holding that the statute made an unconstitutional discrimination between two classes of aliens, declarants and nondeclarants. The validity of the law apart from this discrimination was given very slight consideration.

Justice Butler, delivering the opinion of the Court, seems to have assumed that it was settled by prior decisions. He said, " . . . each State, in the absence of any treaty provision to the contrary, has power to deny to aliens the right to own land within its borders. Hauenstein v. Lynham, 100 U.S. 483, 484, 488; Blythe v. Hinckley,

122 The cases most often assumed to be in point are Hatenstein v. Lynham (1879) 100 U.S. 483, and Blythe v. Hinckley (1901) 180 U.S. 333. In the Hauenstein case the question was whether Swiss nationals, nonresidents of Virginia, could take lands in Virginia by inheritance. It was held that a treaty with Switzerland gave the Swiss heirs the right to inherit. It was assumed, though clearly not decided, that if there had been no treaty, Virginia law against nonresident aliens taking Virginia land by inheritance would have been valid. The sole remarks of the Court on this point were that by international law every government may give to foreigners only such rights with respect to immovable property as it sees fit, and "In our country, this authority is primarily in the States where the property is situated" ( $100 \mathrm{U}$.S. at 484 ), subject to being overriden by treaty.

In the Hinckley case the Court affirmed the decision of the Californin supreme court holding that a state statute granting to aliens the privilege of landowning does not infringe the treaty power of the national government (see supra note 114) and said, "This court has held from the earliest times in cases where there was no treaty that the laws of the State where the real property was situated governed the title and were conclusive in regard thereto." 180 U. S. at 341 . For this were cited Clarke v. Clarke (1900) 178 U. S. 186, and De Vaughn v. Hutchinson (1897) 165 U. S. 566, which presented no issue whatever about aliens. Also Chirac v. Chirac (1817) 15 U.S. (2 Wheat.) 259 was cited, a case holding tbat a treaty supersedes a state statute in conflict therewith.

None of the cases passed on the question whether a state law which deprives resident aliens of the privilege of holding real estate is a denial of equal protection of the laws.

123 (1923) 263 U.S. 197.

124 WASH. REV. STAT. (Remington, 1933) $\$ \$ 10,581,10,582$. 
180 U.S. 333, 340."125 The cited cases contain nothing but meager dicta. $^{128}$

After the above-quoted passage, Justice Butler gave a brief digest of the common-law rules, and added, "State legislation applying alike and equally to all aliens, withholding from them the right to hold land, cannot be said to ... transgress the due process clause."120 Turning to the equal protection clause he distinguished the decision in Truax $v$. Raich, ${ }^{128}$ which he abstracted as holding that a state may not discriminate between citizens and resident aliens with respect to "the right to work for a living in the common occupations of the community." Then follows this sentence:

"In the case before us, the thing forbidden is very different. It is not an opportunity to earn a hiving in common occupations of the community, but it is the privilege of owning or controlling agricultural land within the State." 129

Since when did farming as a farm owner cease to be a "cominon occupation" as a means of earning a livelihood? At the time the Constitution was adopted it was estimated that nine-tenths of the gainfully employed people in America were engaged in agricultural pursuits, ${ }^{130}$ and this was still substantially true in many states when the Fourteenth Amendment was adopted.

But passing that, we come to the next sentence:

"The quality and allegiance of those who own, occupy and use farm lands within its borders are matters of highest importance and affect the safety and power of the State itself."131

In what respect does the ownership of some of the farm lands in a state by persons who owe no allegiance to the United States affect the safety of a state, either in time of peace or of war? Has this ancient idea by which early English law writers rationalized the exclusion of all but the King's subjects from certain feudal land tenures any validity in our tine? Tenure by knight service, or military tenure, was then conceived of as something that none but persons under allegiance to the King might owe. But "by the end of the thirteenth

125263 U.S. at 217.

126 See supra note 122.

127263 U.S. at 218. (Emphasis added.)

128 (1915) 239 U.S. 33.

120263 U.S. at 221.

180 Coxe, A VIEW of the UNITEd States of Awrerca (London ed. 1795) p. 6.

181263 U.S. at 221. (Emphasis added.) 
century, tenure by knight service had ceased to provide either soldiers or their pay." ${ }^{132}$ Maitland says that if it had been abolished in 1300 the military strength of the realm would have been unaffected. ${ }^{133}$ When the statute of $1660^{134}$ completely abolished military tenure it was merely clearing away what had long been a dead letter so far as military service was concerned. A connection between tenure and military service had existed only in theory when Coke saw "destruction of the realm" in landholding by aliens. In our time liability to military service is not dependent upon allegiance. Resident aliens are now subjected to compulsory military service even in international warfare, ${ }^{135}$ and nothing but legislative policy exempts enemy aliens. An alien is not exempt from draft because he owns farm land. So also Coke's Trojan-horse idea, that aliens owning land "might fortify themselves in the heart of the realm", never had any validity in the United States, certainly not since 1798. Congress then passed a statute, ${ }^{136}$ ever since in force, authorizing the arrest, confinement, or removal of enemy aliens in wartime. It also authorized the President "to direct the conduct to be observed, on the part of the United States, toward" enemy aliens. During the war of 1812 with Great Britain, orders by the President and other officials acting under his authority directed all British nationals, fourteen years of age and over, residing within forty miles of tidewater to surrender to United States marshalls and be retired further into the interior of the country or to be kept in close confinement. ${ }^{137}$ In terms of the greater rapidity of travel and transportation in our time, such removal was the equivalent of a removal of enemy aliens five hundred miles from the coast. The evacuation of Japanese enemy aliens from the Pacific Coast during the still legally existing war was not a novelty, although the evacuation of American citizens of Japanese ancestry was un. precedented.

The fact that an enemy alien owns farm lands in nowise affects his liability to evacuation. Indeed the ownership of any property by an enemy alien in the Umited States is an asset to us, rather than a liability or a handicap, in view of the authority given the Alien Prop-

132 HoLDSWORTE, HISTORTCAL INTRODUCHON TO THE LAND LAW (1927) 26.

133 Poliock and MatrLaNd, History of ENGLise LAW (2d ed. 1898) 276.

$13 \pm 12$ CAR. II (1660) c. 24.

135 Formerly writers contended that international law was to the contrary. See

McGovney, Cases on Constitutionar Law (1935) 438.

1361 STAT. (1798) 577 ; R. S. $\$ 4067$, 50 U. S. C. (1940) § 21.

137 See Lockington v. Smith (1817) 15 Fed. Cas. 758. 
erty Custodian to seize it, hold it, sell it or otherwise deal with it in the interest, and for the benefit, of the United States. ${ }^{138}$

Coke's Trojan horse now lives only in law books or in the minds of persons who unthinkingly accept antiquated "reasons" for the ancient discrimination that the common law made against aliens with respect to land holding.

Turning to peacetime, how does alien landholding then affect the safety of the state? I think the complete answer was given to that question by Chief Justice Redfield of Vermont in 1853. The question before the Vermont supreme court was whether the common law against landholding by aliens had been received, or had survived, in the state, and in particular whether Vermont law contained any procedure for the forfeiture of estates of aliens. The court held "no", the Chief Justice saying, "it must, I think, be regarded as questionable how far any such procedure could ever be enforced, for the mere purpose of escheating to the State the lands of a quiet resident or non-resident alien, in time of profound peace, where no danger was apparent, imminent, or even remotely threatened." 139

If the allegiance of farm owners is of "highest importance" and the alienage of farm owners affects the safety of the state, the legislators of forty-one of our states ${ }^{140}$ are lacking in statecraft, for by their laws the allegiance of those who own farm lands is regarded as of no significance whatever. Rightly included in the forty-one states are the nine "ineligible alien" land law states for they also regard the allegiance of landowners of no significance except in case of the small number of aliens racially ineligible to naturalization. So Califorma lawmakers see no reason for denying to a half million alien residents the privilege of owning land without limit, though denying that privilege to less than thirty thousand other alien residents because of their race.

Consequently it seems that a strict apphication of the accepted interpretation of the equal protection clause would nullify any state law that confines landholding to citizens, because of its irrational discrimination against resident aliens. The Supreme Court, however, in Terrace $v$. Thompson ${ }^{141}$ assumed the contrary upon slight consideration, and passed to what it conceived to be the only doubtful

138 U. S. Government Manual (2d ed. 1945) 70.

139 State v. Boston, Concord \& Montreal R. R. Co. (1853) 25 Vt. 433, 440.

140 Supra pp. 21 et seq.

141 Supra note 123. 
question in the case. This was whether the Washington law violated the equal protection clause because it discriminated between two classes of resident aliens, those who had and those who had not made declarations of intention to become citizens. On the premise assumed, that a state could restrict landholding exclusively to citizens, this was an easy question. The Washington law merely made a dispensation in favor of near-citizens, giving them the rights of citizens in landholding. It extended citizen rights to those aliens, regardless of race or national origin, who had "in good faith" made declarations of intention to become citizens. Since it is exceptional that such declarations are not followed through to final naturalization, declarants are rightly regarded as near-citizens, as persons in the process of becoming citizens. The dispensation in their favor is the saine as that formally made in twenty-two states and territories ${ }^{142}$ in granting declarant aliens the right to vote in anticipation of their acquiring citizenship within a few years. That the Washington lawmakers regarded declarants as near-citizens, with a high probability of soon becoming citizens, is shown by the requirement that the declaration of intention be made in good faith, coupled with the statutory presumption: "Unless an alien who has declared his intention to become a citizen of the United States be admitted to citizenship within seven years after his declaration was made, it shall be presumed that he declared his intention in bad faith." ${ }^{143}$ It is curious that the only reported cases in which declarants have been found to have made their declarations in bad faith are those of two white aliens, nationals of Switzerland, and land acquired by them was forfeited. ${ }^{144}$

On the saine day that the Supreine Court announced its decision on the Washington law, it announced its decision in Porterfield $v$. $W e b b{ }^{145}$ upholding the basic features of the California law. The constitutional issue with respect to the latter was disposed of in less than a full page of the opimion, delivered by Justice Butler. The short passage opens with, "This case is similar to Terrace v. Thompson", and closes with, "Our decision in Terrace v. Thompson ... controls the decision of all questions raised here." 140

A patient examination of the two laws discloses that their dis-

142 Aylsworth, The Passing of Alien Suffrage (1931) 25 AMr. Pox. Scr. Rev. 114.

143 Wash. Rev. STat. (Remington, 1933) § 10,586.

144 State v. Staeheli (1920) 112 Wash. 344, 192 Pac. 991 ; State v. Rychen (1920)

113 Wash. 90, 193 Pac. 220.

145 (1923) 263 U.S. 225.

146 Ibid. at 233. 
criminations are very different both in the character of the aliens they affect and in the number of aliens affected. The language which the two laws use in defining their proscribed classes necessarily produces wide differences of application. The Washington law proscribes the alien who has not in good faith declared his intention to become a citizen. Its discrimination is not exclusively racial, whereas the California discrimination is that and nothing inore. I doubt whether the Supreme Court fully appreciated the latter point. When we first read the California law which says, "All aliens eligible to citizenship under the laws of the United States" Inay acquire interests in realty, and other aliens may not, we assume that all aliens imeligible to naturalization are denied the privilege. Was the Supreme Court fully aware that Califorma intended to make that mean only those aliens who are racially ineligible to naturalization? Taken at its face value the expression "aliens ineligible to naturalization" includes every alien who does not reside in the United States, regardless of race; and indeed every alien residing in the United States who has not resided here five years. But the California law is imterpreted to permit every alien in the world to hold realty in Califorma except aliens of the proscribed races.

Also, no alien is eligible to naturalization unless he speaks the English language, but the Califorma law is interpreted not to make that requirement for landholding.

By interpretation California has read the law as saying "All aliens [racially] eligible to citizenship" may acquire mterests in realty and others may not. Thus in its application to aliens residing in Califorma it bars from acquiring any legal interest in realty about twenty-five thousand Japanese aliens and a very few Polynesian and Malayan aliens, and no other resident aliens.

The Washington law, on the other hand, while it also bars aliens racially imeligible to naturalization, because they are legally incompetent to inake declarations of intention, bars them as a small portion of the millions of other aliens who are legally incompetent to make declarations of intention, for reasons apart from their race, as well as those who though competent, do not choose to make declarations. Thus no alien who does not reside in the United States may acquire realty in Washington, except by inheritance or in collection of a debt, ${ }^{147}$ because a declarant is required to state a place of resi-

14i But acquisitions by these excepted modes may be held for no more than twelve years. WASH. REv. Stat. (Remington, 1933) $\$ 10,584$. 
dence in the United States and to declare that he intends to reside permanently in the United States. ${ }^{148}$ The untold inillions of aliens thus excluded from landholding in Washington regardless of their race are eligible to acquire realty in California except those who are members of particular races. Other requirements for a valid declaration of intention make some resident aliens ineligible to acquire land in Washington, regardless of their race. Thus a declarant must declare that he has reached the age of eighteen years. So also he must state facts establishing his lawful entry into the United States. ${ }^{140}$ By contrast, aliens however young, and illegally entered aliens, are not forbidden to acquire realty in California unless they be of the proscribed races.

The reports of cases in the supreme court of Washington, to search no further, show that the Washington law has been applied to white aliens: a British national, ${ }^{150}$ Swiss nationals, ${ }^{151}$ and a German national. ${ }^{152}$ Washington also, like California, bars certain corporations from acquiring realty. In California the proscribed corporations are those in which a majority of the stock is owned by aliens racially meligible to become citizens. In Washington, the proscribed corporations are those in which a majority of the stock is held by nondeclarant aliens, and that rule has been enforced against corporations whose nondeclarant stockholders were obviously white although the reported cases do not specifically state that irrelevant fact. ${ }^{153}$

It is significant that the substantive rules of the Washington law were adopted before the agitation against the Japanese began in the Pacific coast states. They came $\mathrm{m}$ as article II, section 33 of the constitution of $1889,{ }^{154}$ which was self-operative and was judicially en-

1488 U.S. C. (1940) § 731.

140 Ibid.

150 State v. O'Connell (1922) 121 Wash. 542, 209 Pac. 865.

151 State v. Staeheli; State v. Rychen, both sicpra note 144.

152 Abrams v. State (1907) 45 Wash. 327, 88 Pac. 327.

153 See Oregon Mortg. Co. v. Carstens (1896) 16 Wash. 165, 47 Pac. 421 ; State v. Hudson Land Co. (1898) 19 Wash. 85, 52 Pac. 574 (when the land was acquired a majority of the stock was owned by citizens, but later was bought by nondeclarant aliens, and the land was escheated); State v. Superior Court (1903) 33 Wash. 542, 74 Pac. 686. See also the threatened proceedings involved in Northport Power \& Light Co. v. Hartley (1929) 35 F. (2d) 199.

154 "The ownership of lands by aliens, other than those who in good faith have declared their intention to become citizens of the United States, is prohibited in this State, except where acquired by inheritance, under mortgage or in good faith in the ordinary course of justice in the collection of debts .... Every corporation, the majority 
forced, by forfeiture of realty acquired in violation of its provisions. ${ }^{155}$ The statute of 1921 passed upon by the Supreme Court merely supplemented the constitutional provisions by adding procedural devices for enforcement.

The alien whose right to acquire land in Washington was under contest in Terrace v. Thompson was a Japanese. For that reason the effect of the Washington law to deny landholding to aliens legally incompetent to be declarants, as well as to the legally competent who abstained from making declarations, was discussed by Justice Butler. He pointed out that the criteria for classification in the Washington law was not racial eligibility to naturalization:

"The inclusion of good faith declarants in the same class with citizens does not unjustly discriminate against aliens who are ineligible or against eligible ahens who have failed to declare their intention. The classification is based on eligibility and purpose to naturalize."158

He immediately proceeded to discuss the naturalization law's rules on racial eligibility to naturalization. He did not advert to the other requirements for making a declaration of intention, which as pointed out above, render legally incompetent millions of aliens regardless of race. He was fully aware, however, that aliens racially ineligible to naturalization are hit by the Washington law, because they fall within a wider category which includes them and countless others. Thus he says, "All persons of whatever color or race who have not declared their intention in good faith to become citizens are prohibited from so owning agricultural lands." 157 The size of the class in which the racially ineligible aliens are embraced is more fully

of the capital stock of which is owned by aliens, shall be considered an alien for the purposes of this prohibition."

By this provision Washington adopted a change of policy. By the Territorial Statute of January 27,1864 , all aliens had been given equal riglrts with citizens in acquiring and holding interests in realty. Wasl. Stats. $1864, \mathrm{p} .12$. This continued to be the law until 1886 when a statute excepted aliens "such as by the laws of the United States are incapable of becoming citizens." Act of January 29, 1886, Laws 1877-1888, p. 309. I have found no prior appearance of this idea in American law. It may have been the model for the California statute of 1913. Since there were few Japanese in the United States in 1886, the Washington statute may have been motivated by hostility to the Chinese. Compare article XV, section 8, of the Oregon constitution of 1859 , declaring that "no Chinaman" should hold realty in Oregon, and see Chapman v. Toy Long (1876) 5 Fed. Cas. 497. There seem to be no reported cases arising under the Washington Statute of 1886 , and it was supplanted by the very different provisions of the constitution of 1889 .

155 See cases cited supra notes $152,153$.

150263 U. S. at 219. (Einpluasis added.)

157 Ibid. at 220. 
seen when it is realized that it includes all nonresident aliens regardless of race. It was in this connection that Justice Butler wrote the oft-criticized statement:

"Two classes of aliens inevitably result from the naturalization laws, - those who may and those who may not become citizens. The rule established by Congress on this subject, in and of itself, furnishes a reasonable basis for classification in a state law withholding from aliens the privilege of land ownership as defined in the act."16s

Here the Justice may not have been thinking solely about the racial classification of the naturalization law, but of that together with all its other nonracial criteria of classification, such as continuous residence in the United States for five years, ability to speak English, ability to write one's name, attachment to the principles of the Constitution, and others. ${ }^{159}$ More pertinent to the Washington case would have been the naturalization law's criteria for determining competency to make a declaration of intention.

On the other hand, unless the passage last quoted referred solely to the racial classification made by the naturalization law, how could Justice Butler justify his statement in Porterfield v. Webb, that "Our decision in Terrace $v$. Thompson controls the decision of all questions raised" by the California law?

The California law's discrimination between two classes of aliens is based solely and exclusively on the naturalization law's racial classification, disregarding all of its nonracial criteria for determining eligibility to naturalization.

In the Washington case, a state law is sustained which confines landholding to citizens and near-citizens, which denies the privilege to aliens racially ineligible to naturalization because they fall within a class not defined in terms of race, but one defined by very different criteria and which necessarily embraces a vast number of aliens irrespective of their race. In short, the Washington law closely approximates the common law's restriction of landholding to citizens, with a dispensation in favor of aliens in the process of becoming citizens.

How does sustaining that law necessarily determine the constitutionality of the California law? The latter law makes no attempt to confine landholding to citizens, or to citizens and near-citizens. Millions of nonresident aliens incompetent to make declarations of intention may acquire land in California; millions of nonresident 
aliens ineligible to naturalization may do so; even a half million resident aliens, regardless of whether they would or could become declarants and regardless of whether they could qualify for naturalization, may own and hold land in California. The sole exclusion by the California law is those aliens who are racially ineligible to naturalization.

How can it be said that a racial discrimination made by Congress in determining what aliens may become citizens "in and of itself, furnishes a reasonable basis for classification in a state law withholding from [some] aliens the privilege of land ownership"? A discrimination made for one purpose is necessarily rational for another purpose? A discrimination made for one purpose by a legislature that is subject to no equalitarian requirement justifies another legislature in making a like discrimination for another purpose although the latter is subject to an equalitarian requirement?

Justice Butler rightly said, "Congress is not trammeled, and it may grant or withhold the privilege of naturalization upon any grounds or without any reason, as it sees fit." 160

He added, "But it is not to be supposed that its acts defining eligibility are arbitrary or unsupported by reasonable considerations of public policy." 161 Quite so, as an a priori supposition, but in reality it is difficult to find any reasonable considerations underlying the crazy quilt patternlessness of our naturalization law, which bars from naturalization because of their race Japanese Mongolians but not Chinese Mongolians, Malays if they are Siamese but not if they are Filipinos, and admits people indigenous to the Western hemisphere and to British India regardless of their ethnological classification. Moreover this patternless racial bar operates against individuals regardless of their culture, education, or personal fitness in other respects to exercise the privileges of citizenship. Moreover also, the public policies that are germane to determining what aliens should be permitted to become citizens lie in the field of political rights. The national government is concerned in determining what persons may become eligible to diplomatic protection of the United States and possibly also what persons shall become entitled to the protection which the Constitution gives citizens with respect to voting. The naturalization law expresses no judgment of Congress with respect to who should be permitted to own lands within the states, a matter 
not within the competency of Congress. To ascertain the judgment of Congress on that point we must look to its legislation for the Territories. There we find that "any alien who shall become a bona fide resident of the United States ... shall have the right to acquire and hold lands in either of the Territories of the United States upon the same terms as citizens of the United States." 102

Under the equal protection clause the validity of a state discriminatory law turns upon whether there is a rational relation between the discrimination and the purpose of that law.

Repeatedly the Court has said that a state law's discrimination to be constitutional must be "based on a real and substantial difference having a reasonable relation to the subject of the particular legislation." "183

All that Justice Butler offered on the rationality of the "ineligible alien" land law was that it was enacted out of concern for the "safety of the state" in some unspecified respect. In $W e b b v$. O'Brien, ${ }^{104}$ sustaining the California law as one prohibiting ineligible aliens to farm under crop-sharing contracts, he said, "Conceivably, by the use of such contracts, the population living on and cultivating the farm lands might come to be nuade up largely of ineligible aliens. The allegiance of the farmers to the state directly affects its strength and safety." 105 Even if the allegiance of farmers had significance why is it of significance with respect to the less than thirty thousand "ineligible aliens" in California but of no significance with respect to a half million other aliens in California who may never seek or acquire citizenship? Moreover, the statement smacks of Coke's exaggeration when he said that if aliens could hold land in England, there would not be enough British freeholders to man the juries. ${ }^{108}$ If all the "ineligible aliens" in California were to exhaust themselves in share cropping, there would be millions of acres of farm lands left for the citizens and other aliens. The same exaggeration is found in a statement with which Justice Butler said he agreed: "If one incapable of citizenship may lease or own real estate, it is within the realm of possibility that every foot of land within the state might pass to

1628 U.S.C. (1940) § 72.

163 Power Co. v. Saunders (1927) 274 U.S. 490, 493 ; Quaker City Cab Co. v. Pennsylvania (1928) 277 U.S. $389,400$.

104 (1923) 263 U.S. 313.

165 Ibid. at 324.

166 Supra note 45. 
the ownership or possession of noncitizens." ${ }^{167}$ Even if that were a possibility the evil inherent therein is not specified.

Twice the supreme court of California has said that the purpose of her law is to reserve the lands of the state for citizens. Thus: "The ownership of the soil by persons morally bound by obligations of citizenship is vital to the political existence of a state." 168 "Unquestionably the farming of lands by ineligible aliens would give them a use, occupancy, and benefit of agricultural lands which in effect would anount to a deprivation of its use, enjoyment and occupancy by the citizen." 160

In a recent case in the suprenre court of California the state's Attorney General said: "We believe it may be said that, in a very real sense, ownership of the land by its citizens, or those qualified to become such, may be regarded as a sine qua non to the self-preservation of a free country."170

The demial of a common economic opportunity to a small portion of the residents of a state is essential to "the self-preservation of a free country"!

Are not all these remarkable assertions that the California law is intended to reserve the lands for its citizens belied by the fact that all the aliens in the world either as individuals or under corporate organization may legally acquire land in Califormia without limit, unless the individuals be of particular races, or a majority of the corporate stock is held by aliens of particular races?

In vain we search for the purpose of the California law. Another former Attorney General of California, Ulysses S. Webb, asserted another purpose for it, and he had been active in drafting, and later in the enforcement of the law. In argument in Frick $v$. Webb $b^{171}$ he said:

"It was the purpose of those who understood the situation to prohibit the enjoyment or possession of, or dominion over, the agricultural lands of the State by aliens ineligible to citizenship,-in a practical way to prevent ruinous competition by the Oriental farmer against the American farmer." 112

107263 D.S. at 220.

168 Mott v. Cline, supra note 84, at 447, 253 Pac. at 724.

169 Porterfield v. Webb, supra note 83, at 82, 231 Pac. at 558.

170 Brief for Respondent, p. 11, State v. Oyama (1946) 29 A. C. 157, 173 P. (2d) 749. 171 Supra note 112.

172 Ibid. at 330 . 
No doubt this motive actuated some of the voters in approving the Initiative Act of 1920. The argument raises the issue whether prevention of competition is a constitutionally permitted purpose for which a common type of economic opportunity may be denied to a class of residents distinguished from all others solely by their race. The statutorily declared purpose "to protect the citizens of the United States in their employment against non-citizens of the United States" did not save Arizona's anti-alien law which was held invalid in Truax $v$. Raich ${ }^{173}$ on the ground that it irrationally denied resident aliens a common type of economic opportunity.

Where a state discriminatory statute has a legitimate purpose the Supreme Court has paid great deference to the local legislature's judgment that the discrimination is rationally related to that purpose. ${ }^{174}$ Such deference was shown in sustaining state legislation denying to all aliens, without distinction, licenses to operate pool and billiard rooms. Justice Stone, speaking for the Court, said:

"The admitted allegations of the answer set up the harmful and vicious tendencies of public billiard and pool rooms, of which this Court took judicial notice in Murphy v. California, 225 U.S.. 623. The regulation or even prohibition of the business is not forbidden. Murphy v. California, supra. The present regulation presupposes that aliens in Cincinnati are not as well qualified as citizens to engage in this business. It is not necessary that we be satisfied that this premise is well founded im experience. We cannot say that the city council gave unreasonable weight to the view admitted by the pleadings that the associations, experiences and interests of members of the class disqualified the class as a whole from conducting a business of dangerous tendencies.

"It is enough for present purposes that the ordinance, in the light of facts admitted or generally assumed, does not preclude the possibility of a rational basis for the legislative judgment and that we have no such knowledge of local conditions as would enable us to say that it is clearly wrong. Fort Smith Light \& Traction Co. v. Board of Improvement, ante, p. 387."175

If some evil condition in farning existed in any state, the state might set up a licensing system for farmers and prescribe qualifications deemed essential to overcome the evil, and the Supreme Court would doubtless pay deference to the local judgment on the ration-

173 (1915) 239 U.S. 33.

174 Missouri, Kansas \& Texas Ry. Co. v. May (1904) 194 U.S. $26 \%$.

175 Clarke v. Deckebach (1927) 274 U. S. 392, 397. 
ality of the discrimination made thereby. Thus if tillable land were scarce in California relative to the food needs of her population, the state might prescribe qualifications for farming that would exclude all not well qualified as productive operators. If such was the purpose of the California law it fits ill with the fact that the chief charge against "ineligible aliens", and the Japanese in particular, was that they were especially skillful and unduly industrious-particularly in intensive cultivation, involving hard personal labor. It would take a high degree of judicial deference to local judgment to believe that Japanese were the worst offenders in nonproductivity. There would be little room for applying the Court's doctrine: "If the law presumably hits the evil where it is most felt, it is not to be overthrown because there are other instances to which it might have been applied." 176

The truth is that the real purpose of the California "ineligible alien" land law was to nuake the residence of Japanese in the state as little attractive as possible. Since the state lacked constitutional power to drive them across its borders by direct legislation, the attempt was made to approximate that objective by indirection. It had the same motive as the earlier agitation against the Chinese under the slogan "The Chinese must go". ${ }^{177}$ In consequence the law denied to Japanese economic opportunity of a kind for which they had shown aptitude. Recent enactments of the legislature disclose that this motive persists, even against the small remnant of aged Japanese aliens now living in the state. One of these is a law with respect to who may obtain licenses for commercial fishing, enacted in 1943 and amended in 1945. A prior statute of $1933^{178}$ granted this privilege to any "person", alien or citizen, "who has continuously resided within the United States for a period of one year imniediately prior" to application. In 1943 this was amended to read, "A commercial fishing license may be issued to any person other than an alien Japanese." 179 In 1945 a committee of the legislature reported:

"The committee, however, feels that there is danger of the present statute being declared unconstitutional, on the grounds of discrimination, since it is directed at alien Japanese. It is believed that this legal question can probably be eliminated by an amendment which has

176 Radice v. New York (1924) 264 U. S. 292, 298.

177 See Appendix A.

178 Cal. Stats. 1933, p. 479 ( $\$ 990$ ).

170 Ibid. 1943 , p. 3040. 
been proposed to the bill which would make it apply to any alien who is ineligible to citizenship."

This recommendation resulted in enacting the provision now in force: "A commercial fishing license may be issued to any person other than a person ineligible to citizenship." Obviously that last phrase means racially ineligible and includes a trifling number of other alien residents of Califorma along with the Japanese. Does this clever inclusion of a few other aliens, also determined by their race, save the law?

Will courts refuse to take judicial notice of the purpose of this law as shown by its legislative history? Even if they do refuse will it make any difference? The circumlocutionary phrase "ineligible to citizenship" has the same meaning as the phrase "aliens incapable of becoming electors of this State" in a California statute of $1880,{ }^{180}$ which prohibited fishing by such aliens. A circuit court of the United States held that the latter denied to Chinese the equal protection of the laws. ${ }^{181}$ The court said, "It is obvious, . . considered in connection with the public history of the times, that the act relating to - fishing in question was not passed in pursuance of any public policy relating to the fisheries of the state as an end to be attained, but simply as a means of carrying out its policy of excluding the Chinese from the state, contrary to the provisions of the treaty." 182

Likewise the statute of 1945 cannot be regarded as a fish-conservation measure since any person whatsoever may obtain a commercial fishing license except "ineligible aliens" of whom less than thirty thousand, men and women, reside in the state, and the persons eligible include a half-million other alien residents.

That to discourage the residence of alien Japanese in California is the legislative objective, and that the denial of particular economic opportunities is merely a means to that end, is further shown by the joint resolution of the legislature in 1944 petitioning Congress to provide for the deportation, at the end of the war, of all Japanese nationals residing in the United States. ${ }^{183}$

In the search for the purpose of California's discriminatory laws against "ineligible aliens" we end in finding that the purpose is to induce the withdrawal from the state of alien residents of a particular race or races, a purpose not within a state's competency. In con-

180 Ibid. 1880, p. 123.

181 In re Ah Chong (1880) 2 Fed. 733.

$182 \mathrm{Ibid}$. at 737.

183 Cal. Stats. 1945, p. 101. 
sequence, therefore, discussion whether the discrimination made in these laws has a rational relation to any legitimate state purpose seems uncalled for. How does this legislation differ from the San Francisco laundry ordinance under which none but Chinese were denied licenses? Of that ordinance the Supreme Court of the Umited States said:

"The fact of this discrimination is admitted. No reason for it is shown, and the conclusion cannot be resisted, that no reason for it exists except hostility to the race and nationality to which the petitioners belong, and which in the eye of the law is not justified. The discrimination is, therefore, illegal, and the public administration which enforces it is a denial of the equal protection of the laws and a violation of the Fourteenth Amendment of the Constitution." 184

A statute of the Philippines forbade "any person" to keep his business accounts "in any language other than English, Spanish, or any local dialect." The Supreme Court took judicial notice of the legislative history of the act, and said:

"Nor is there any doubt that the Act, as a fiscal measure, was chiefly directed against the Chinese merchants. The discussion over its repeal in the Philippine Legislature leaves no doubt on this point. So far as the other merchants in the Islands are concerned, its results would be negligible and would operate without especial burden on other classes of foreign residents." 185

The Court quoted" from a former opinion: "The question in each case is whether the legislature has adopted the statute in exercise of a reasonable discretion, or whether its action be a mere excuse for an unjust discrimination, or the oppression, or spoliation of a particular class." 187

The Court concluded that the Philippine statute was "obviously intended chiefly to affect" the Chinese and was a denial to them of equal protection of the laws. ${ }^{188}$ The opinion by Chief Justice Taft makes it clear that if the Philippine statute had confined its requirement to the keeping of particular accounts in a language known to public officials for the purpose of aiding detection of sales-tax evasions and had allowed Chinese to keep duphicates in their own lan-

181 Yick Wo v. Hopkins (1886) 118 U. S. 356, 374.

186 Yu Cong Eng v. Trinidad (1926) 271 U.S. 500, 514.

$180 \mathrm{Ibid}$. at 526.

187 Holden v. Hardy (1898) 169 U. S. 366, 398.

188271 U. S. at 528. 
guage, the statute might have been sustained. The Court, however, found no purpose for the sweeping provision of the statute to which its discrimination was rationally related.

In 1925 Justice Butler, in summarizing his three opinions of 1923, in which the California law had been sustained, said that they rested on the proposition that "The State has a wide discretion and may classify persons on bases that are reasonable and germane having regard to the purpose of the legislation." 189

In thus supposing that the long-settled interpretation of the equal protection clause had been applied in those decisions there seems to be error, through failure of the Court to penetrate to the purpose of the California law and through failure to fully consider whether it had any legitimate purpose to which its narrow and purely racial discrimination is germane.

\section{APPENDIX A}

THE ANTI-CHINESE LEGISLATION OF CALIFORNIA

California legislation against Orientals prior to 1913 was directed against the Chinese. In all the flood of discriminatory measures, however, the legislature made no attempt to curtail the rights of Chinese to hold land, and in that respect Chinese aliens in California had equal rights with citizens.

The period of anti-Chinese legislation ran from 1855 to 1891. At the end of that period there were about 107,000 Chinese in the continental United States, or 126,778 in the United States including Alaska and Hawaii. ${ }^{190}$ Of these, 72,472 , mostly aliens, ${ }^{191}$ resided in California. This was a decrease since 1880 , and so rapidly did the number continue to decrease that in 1910 there were only 27,778 alien Chinese and 8,470 American-citizen Chinese in the state. In 1890 it was believed by local observers that there were "twenty-odd thousand" Chinese in San Francisco, the chief center of anti-Chinese agitation. ${ }^{192}$

During the period of anti-Chinese legislation there were few Japanese in California. In 1860 there were none, in 1870,33; in 1880, 86; in 1890, 1147 , almost all foreign-born. The census shows no American-born Japanese in California until 1900, the number then being 143. In that year 10,008 alien Japanese were reported as residing in California. In 1910 the number was 38,184 . By that time California's hostility had shifted from the Chinese to the Japanese. It may be added that by 1920 the number of alien Japanese in California had increased to 51,138 , which was the peak,

189 Cockrill v. California (1925) 268 U.S. 258, 262.

190 12th Census of the United States: 1900, Population, Vol. I, p. cxxiii.

191 The Census of 1890 did not distinguish between the foreign born and the American born, except with respect to males, giving 64,065 as the number of China-born males residing in California.

192 See In re Lee Sing (1890) 43 Fed. 359, 361, and Wong Wai v. Williamson (1900) 103 Fed. $1,6$. 
for the number has progressively declined ever since. At no time were the alien Japanese as numerous in California as were the Chinese in 1880, then numbering about 75,000.

The anti-Chinese laws and ordinances in soine instances expressly named the Chinese as the only persons affected, while in other instances phrases of "indirection and circumlocution", as United States Circuit Judge Sawyer called them, ${ }^{193}$ were used for the same purpose. Both the state and federal courts were astute to take judicial notice that it was the intention of the lawmakers to hit the Chinese only, and dealt with these laws and ordinances accordingly. The intentions of the American people in adopting the equal protection clause of the Fourteenth Amendment were fresh in the minds of these judges and they applied it in accordance with those intentions, although some of the anti-Chinese legislation was held to violate other provisions of the Constitution, particularly the commerce clause, and sonie of it to be in violation of treaty rights of the Chinese. The nuotives of the legislation against the Chinese were the same as those of the later legislation against the Japanese: to prevent or discourage their coming, and to induce those who had come to depart. At bottom the tactics were the same: to hit them where it hurt most, to deny them economic opportunities of the kinds they preferred. The Chinese, however, were not denied the right to own farm land because few of them engaged in farming.

A brief summary of California's anti-Chinese legislation follows. ${ }^{194}$

A statute of $1855^{105}$ required any shipniaster who brought into Cahfornia "any persons who are incompetent by the laws of the United States ... to becoine citizens" to pay a fifty dollar tax for each person. The Cahfornia supreine court held that this statute was an invasion by the state of the exclusive power of Congress under the commerce clause, and said, "We, therefore, decide that the act of this State, laying a tax of fifty dollars each on Chinese passengers, is invalid and void."106

In 1853 a uniform license fee was imposed upon all alien gold mmers, ${ }^{197}$ without distinction, but a statute of 1855 niade a discrimination by imposing upon "each foreigner ineligible to become a citizen of the United States" a much heavier tax than on other ahen gold miners. ${ }^{198}$ Obviously it was the Chinese gold miner who was hit. The discrimination, however, was repealed the following year. ${ }^{199} \mathrm{~A}$ statute of $1858^{200}$ made it unlawful for "any person, or persons, of the Chinese or Mongolian races" to enter or be brought into the state. This statute it seems was held unconstitutional by the state supreine court in an unreported case. ${ }^{201}$ In 1860 the legislature enacted that

193 In re Ah Chong (1880) 2 Fed. 733, 740.

194 See also, Weinstock and Landis, Right of Chinese Aliens to Take Title to Land (1944) 19 CaL. St. Bar J. 19.

105 Cal. Stats. 1855 , p. 194.

196 People v. Downer (1857) 7 Cal. 169, 171.

197 Cal. Stats. 1853, p. 62.

108 Ibid. 1855, p. 216.

199 Ibid. 1856, p. 141.

200 Ibid. 1858, p. 295.

201 See Lin Sing v. Washburn (1862) 20 Cal. 534, 539. 
"no Chinese or Mongolian" should take fish from the waters of the state without paying a monthly license fee. ${ }^{202}$ This law was entitled "An Act for the Protection of Fisheries".

An act entitled "An Act to protect Free White Labor against competition with Chinese Coolie Labor, and to discourage the Immigration of the Chinese into the State of California" was passed in 1862.203 It levied on "each person, male and female, of the Mongolian race of the age of eigliteen years and upward", except those engaged in a few specified occupations, a monthly tax of $\$ 2.50$, to be known as the "Clinese Police Tax". It is obvious that the legislature used the words "Mongolian" and "Chinese" as synonymous. The state supreme court bore down upon the declared purpose of this act "to discourage the immigration of Chinese" and lield it a violation of the commerce clause, ${ }^{204}$ notwitlistanding that the statute did nothing to accomplish that purpose other than to lay a discriminatory tax on Chinese residents. The Fourteenth Amendment with its equal protection clause lad not yet been adopted.

In 1850 the legislature lad enacted a statute familiar in America from colomial times: "No black or mulatto person, or Indian, shall be permitted to give evidence in favor of, or against, any white person." ${ }^{205}$ In 1863 the legislature, shifting its race prejudice, struck out the words "black or mulatto" and substituted "Mongolian, or Clinese". In 1870 the supreme court of California lield that this statute did not deny to Clinese the equal protection of the laws, ${ }^{206}$ this being the first decision in which that court failed to protect the Chinese from discriminatory legislation.

The constitution of 1879 was adopted at the lieiglit of the agitation against the Clinese. In confining to whites and Negroes its guaranty (article $I$, section 17) that resident aliens sliould lave the same property rights as citizens, it obviously was intended to permit the legislature to restrict the property riglits of resident aliens of other races, including Chinese, but prior to 1913 no sucl legislation was enacted. ${ }^{207}$

Article XIX of the constitution, lieaded "Chinese", directed the legislature to pass all necessary laws: (1) to forbid any corporation formed under the laws of the state to "employ, directly or indirectly, in any capacity, any Clinese or Mongolian"; (2) to forbid employment of "Chinese" on any state, county, municipal, or other public work; (3) to empower cities and towns to require "Chinese" either to remove from them or live in segregated areas therein; and (4) in general to do all in its power to discourage the immigration of "foreigners ineligible to become citizens" and in particular "to prolibit the introduction into this State of Clinese."

The legislature of 1880 hastened to act upon these niandates. Its statute ${ }^{208}$ against employment of Chinese by domestic private corporations was

202 Cal. Stats. 1860, p. 307.

203 Ibid. 1862, p. 462.

204 Lin Sing v. Washburn, supra note 201.

205 Cal. Stats. 1849-1850, p. 230.

206 People v. Brady (1870) 40 Cal. 198.

$20 \pi$ See supra pp. 24-25.

208 Acts Amendatory of the Penal Code, 1880, p. 1. 
held invalid by a United States circuit court as being in conflict with a treaty with China, and also as a denial of equal protection of the laws. ${ }^{209}$

Another statute ${ }^{210}$ authorized cities to enact ordinances to drive out the Chinese or segregate them, though it is now obvious that such ordinances would be unconstitutional. ${ }^{211}$ By a third statute ${ }^{212}$ the catching of fish for sale was forbidden to "all aliens incapable of becoming electors of this State." The use of this formula to define the proscribed class was doubtless suggested by article II of the constitution of 1879 which declared that "no native of China ... shall ever exercise the privilege of an elector in this State."

United States Circuit Judge Sawyer, in holding this statute both in conflict with a treaty and a denial of equal protection, said that it was passed not "in pursuance of any policy relating to the fisheries of the state as an end to be attained, but simply as a means of carrying out its policy of excluding the Chinese from the state ...."213 $\mathrm{He}$ took judicial notice of the history of the times to conclude that the statute's words, "all aliens incapable of becoming electors", meant Chinese, and said that the state could not accomplish an unconstitutional purpose "by indirection and circumlocution".214

Judge Sawyer also intimated that $\bar{a}$ fourth statute ${ }^{215}$ of 1880 was unconstitutional for the same reason. It forbade state or local officials to issue a license "to transact any business or occupation ... to any alien not eligible to become an elector of this State."

In 1891 the legislature prohibited "the coming of Chinese persons into the State, whether subjects of the Chinese Enpire or otherwise." 216 The supreme court of the state held that this statute was "plainly in excess of the power of the State."217

This was the last act of the legislature directed at the Chinese. Several city ordinances against them were also frustrated by the federal courts. Three of them were intended to drive Chinese out of the humble occupation of laundryman [In re Quong Woo, ${ }^{218}$ In re Tie Loy (The Stockton Laundry case $)^{219}$ and $Y_{i c k} W_{0}$ v. Hopkins $\left.{ }^{220}\right]$. In the last case the ordinance was expressed in nondiscriminatory words but arbitrarily adininistered to deny laundry licenses to none but Chinese and for that reason was held a denial to them of equal protection of the laws. The Supreme Court of the United

209 In re Parrott (1880) 1 Fed. 481.

210 Cal. Stats. 1880, p. 22.

211 Buchanan v. Warley (1917) 245 U.S. 60.

212 Cal. Stats. 1880, p. 123.

213 In re Ah Chong (1880) 2 Fed. 733, 737.

214 Ibid. 737, 740.

215 Cal. Stats. 1880 , p. 39.

216 Ibid. 1891, 185.

217 Ex parte Ah Cue (1894) 101 Cal. 197, 198, 35 Pac. 556, 557.

218 (1882) 13 Fed. 229.

210 (1886) 26 Fed. 611.

2200 (1886) 118 U.S. 356. 
States said, "No reason for it [the discrimination] is shown, and the conclusion cannot be resisted, that no reason for it exists except hostility to the race and nationality to which the petitioners belong, and which in the eye of the law is not justified." 221

Another ordinance of San Francisco ordered "all Chinese", both aliens and American citizeus, either to move out of the city or to segregate themselves, both for residence and the carrying on of business, within a prescribed area of the city, and was held invalid by a federal court.222 Two other San Francisco ordinances met the same fate because of their discrimination against the Chinese. ${ }^{223}$

Of all the San Francisco anti-Chmese ordinances the "queue ordinance" of 1876 is the most notorious. On its face it applied to "every male person" imprisoned in the county jail, and provided that upon arrival the hair of his head should be "cut or clipped to an uniform length of one inch from the scalp." In holding that the ordinance denied to Chinese the equal protection of the laws Justice Field took judicial notice of the fact that at that time Chinese men regarded deprivation of their queues a mark of disgrace and that in spite of the generality of its wording "the ordinance was intended only for the Chinese." This was, he said, the intention avowed by the supervisors on its passage, and was so well understood by everyone, that it was known in the community as the "queue ordinance". He said:

\begin{abstract}
"When we take our seats on the bench we are not struck with blindness, and forbidden to know as judges what we see as men; and where an ordinance, though general in its terms, only operates upon a special race, sect or class, it being universally understood that it is to be enforced only against that race, sect or class, we may justly conclude that it was the intention of the body adopting it that it should only have such operation, and treat it accordingly."224
\end{abstract}

It will be noted that some of the statutes and ordinances against the Chinese were enacted after Congress had passed the Chinese Exclusion Act of $1882^{225}$ which was unsatisfactory to anti-Chinese agitators in California because it merely suspended the immigration of Chinese laborers, and for ten years only. The suspension was extended for another ten years in 1892.226 In 1902 Chinese laborers, skilled as well as unskilled, were excluded for the indefinite future. ${ }^{227}$ By the Act of May 26, 1924,,228 all other classes of Chinese were denied entry as "immigrants", that is, for permanent residence. Before the last enactment, however, race prejudice in California had ceased to be directed toward the Chinese. The last remnant of San Francisco's discrimination against them, the segregation of Chinese chil-

221 Ibid. at 374.

222 In re Lee Sing, supra note 192.

223 Wong Wai v. Williamson, supra note 192; Jew Ho v. Williamson (1900) 103 Fed. 10.

224 Ho Ah Kow v. Nunan (1879) 12 Fed. Cas. 252, 255.

225 Act of May 6, 1882, c. 126, \& 1, 22 Srat. (1882) 58.

${ }^{228} 27$ STAT. (1892) 25.

22732 STAT. (1902) 176.

228 § 13(e), 43 STAT. (1924) 162. 
dren, citizens as well as aliens, in the public schools of the city, has fallen quietly into desuetude. The era of the opprobrious epithet, "the heathen Chinee", has become a shameful memory. In 1943 Congress removed the bar of racial ineligibility for naturalization of Chinese, repealed the Chinese Exclusion Acts, and assigned to the Chinese a quota of annual immigrants. ${ }^{220}$ This abolition of discrimination against the Chinese met with hearty approval in California. The fact that making them racially eligible to naturalization causes the "ineligible alien" land acts of 1913 and 1920 no longer to apply to them arouses no resentment. It is a curious commentary upon the earlier dogma that Chinese are unassimilable in America, and upon the former intolerance of Chinese culture and customs, that the Climese are now encouraged to display the latter, as in their celebration of the Chinese New Year, adding color and picturesqueness to the life of the community.

\section{APPENDIX B}

Illinois adheres to the common-law rules with respect to all aliens more closely than any other state. Her deviations from the common law are slight: an alien may acquire realty by descent, and realty held by an alien at his death will pass by his devise or, if he dies intestate, to his heirs. But however acquired, realty held by an alien is subject to forfeiture to the state, as at common law, with this further deviation that the alien is assured a six-year period of lolding before forfeiture proceedings may be begun, to enable him to sell im good faith, giving an indefeasible title, or to preserve his holding by becoming a citizen. ${ }^{230}$

In Kentucky alien declarants have equal rights with citizens in acquiring, holding and transmitting realty, unless they are enemy aliens.231 Other aliens, if residents, may "take and hold" land for a period of twenty-one years for any purpose, it seems, other than agricultural. ${ }^{232}$ In no case is real estate "purchased" by an alien subject to forfeiture until after he las held it eight years and during that time and until actual forfeiture he may alienate an indefeasible title to a purchaser, lessee, heir or devisee, provided the transferee is a citizen. Moreover, the alien may keep the realty if he becomes a citizen within the eight-year period. ${ }^{233}$ The common law is also modified with respect to nonresident aliens by allowing them to take Kentucky realty by descent, but they must alienate it within eight years to escape forfeiture. ${ }^{234}$

Missouri's departures from the common law against realty-holding by aliens are slight. Any alien may acquire realty in Missouri by inheritance, by devise, and by proceedings for the collection of debts, and hold realty so acquired without liability to forfeiture. The statute makes an unclear

220 Act of December 17, 1943, 57 STAT. (1943) 600.

230 Irl. Rev. Stat. (1943) c. 6, §§ 1, 2.

$231 \mathrm{Ky}$. STAT. (1942) § 381.290.

232 Ibid. $\$ 381.320$.

233 Ibid. $\$ 381.300$.

234 Ibid. \$ 381.330. 
reference to alien declarants as if they might have greater rights than other aliens. ${ }^{235}$

So also Nebraska retains much of the common law against the holding of realty by aliens. Any alien, however, may acquire and hold a leasehold in any realty for a term not exceeding five years. A resident alien may acquire title to any realty by devise or descent and hold for five years, or he may acquire title in the course of proceedings to collect a debt due him, and hold for ten years. ${ }^{236}$ Any alien may. "purchase" and hold as much real estate as is necessary for manufacturing establishments or for the storage and sale of petroleum products. ${ }^{237}$

Nevada formerly gave both resident ${ }^{238}$ and nonresident aliens ${ }^{230}$ equal rights with citizens to acquire and hold realty, but since 1924 has made the surprising discrimination of reverting to the common law with respect to resident aliens while still giving nonresident aliens "except subjects of the Clinese empire" equal rights with citizens, with the exception that the acquisition of property by will or by intestacy by a nonresident alien is made dependent upon reciprocal treatment of American citizens by an alien's country. ${ }^{240}$

In Texas the common law against landholding by aliens is in force with some exceptions: (1) it does not apply to land in an incorporated town or city; (2) it does not apply to certain classes of aliens so long as they are residents of the state, viz., (a) alien declarants; (b) aliens who are naturalborn citizens of countries that have a common land boundary with the United States; and (3) any alien probibited from holding is in reality allowed to hold a minimum of five years if he acquires the realty by descent, devise, or in collection of a debt. In other cases forfeiture proceedings may be begun at any time. In any case an alien who acquires a defeasible title may prior to institution of forfeiture proceedings convey an indefeasible title if the conveyance is to a citizen. ${ }^{24 i}$

235 Mo. REv. Stat. (1939) §§ 15228, 15230.

236 NEB. REv. STAT. (1943) §§ 76-402, 76-405, 76-411.

237 Neb. Laws 1945, p. 573.

238 NEv. Const. (1864) art. I, sec. 16, repealed Nov. 4, 1924.

239 Act of February 27, 1879, still in force. NEv. Cosir. Laws (Hillyer, 1929) $\$ 6365$.

240 Act of March 28, 1941. Nev. CoMp. Laws (Hillyer, Supp. 1931-1941) 89894.

241 Tex. Stat. (Vernon, Centennial ed. 1936) arts. 166 et seq. 